\title{
Inferring phytoplankton carbon and eco-physiological rates from diel cycles of spectral particulate beam-attenuation coefficient
}

\author{
G. Dall'Olmo ${ }^{1}$, E. Boss ${ }^{2}$, M. J. Behrenfeld ${ }^{3}$, T. K. Westberry $^{3}$, C. Courties $^{4,5}$, L. Prieur ${ }^{6,7}$, M. Pujo-Pay ${ }^{8,9}$, \\ N. Hardman-Mountford ${ }^{1}$, and T. Moutin ${ }^{10}$ \\ ${ }^{1}$ Plymouth Marine Laboratory, Prospect Place, The Hoe, Plymouth, PL1 3DH, UK \\ ${ }^{2}$ MISC Lab, University of Maine, 458 Aubert Hall, Orono, ME 04469, USA \\ ${ }^{3}$ Department of Botany and Plant Pathology, Oregon State University, Corvallis, OR, 97331, USA \\ ${ }^{4}$ CNRS, UMS2348, Observatoire Océanologique, 66650 Banyuls sur mer, France \\ ${ }^{5}$ UPMC Univ Paris 06, UMS2348, Observatoire Océanologique, 66650 Banyuls sur mer, France \\ ${ }^{6}$ CNRS, UMR7093, Laboratoire d'Océanographie de Villefranche, Observatoire Océanologique, \\ 06234 Villefranche/mer, France \\ ${ }^{7}$ UPMC Univ Paris 06, UMR7093, Laboratoire d'Océanographie de Villefranche, Observatoire Océanologique, \\ 06230 Villefranche/mer, France \\ ${ }^{8}$ INSU-CNRS, UMR7621, LOMIC, Laboratoire d'Océanographie Microbienne, Observatoire d'Oceanologique, \\ 66650 Banyuls/mer, France \\ ${ }^{9}$ UPMC Univ Paris 06, UMR7621, LOMIC, Laboratoire d'Océanographie Microbienne, Observatoire Oceanologique, \\ 66650 Banyuls/mer, France \\ ${ }^{10}$ INSU-CNRS, Laboratoire d'Océanographie Physique et Biogéochimique, UMR6535, Centre d'Océanologie de Marseille, \\ Université de la Mediterranée, France
}

Received: 15 March 2011 - Published in Biogeosciences Discuss.: 21 March 2011

Revised: 10 November 2011 - Accepted: 14 November 2011 - Published: 28 November 2011

\begin{abstract}
The diurnal fluctuations in solar irradiance impose a fundamental frequency on ocean biogeochemistry. Observations of the ocean carbon cycle at these frequencies are rare, but could be considerably expanded by measuring and interpreting the inherent optical properties. A method is presented to analyze diel cycles in particulate beam-attenuation coefficient $\left(c_{\mathrm{p}}\right)$ measured at multiple wavelengths. The method is based on fitting observations with a size-structured population model coupled to an optical model to infer the particle size distribution and physiologically relevant parameters of the cells responsible for the measured diel cycle in $c_{\mathrm{p}}$. Results show that the information related to size and contained in the spectral data can be exploited to independently estimate growth and loss rates during the day and night. In addition, the model can characterize the population of particles affecting the diel variability in $c_{\mathrm{p}}$. Application of this method to spectral $c_{\mathrm{p}}$ measured at a station in the oligotrophic Mediterranean Sea suggests that most of
\end{abstract}

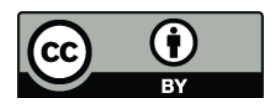
Correspondence to: G. Dall'Olmo
(gdal@pml.ac.uk) the observed variations in $c_{\mathrm{p}}$ can be ascribed to a synchronized population of cells with an equivalent spherical diameter around $4.6 \pm 1.5 \mu \mathrm{m}$. The inferred carbon biomass of these cells was about 5.2-6.0 $\mathrm{mg} \mathrm{m}^{-3}$ and accounted for approximately $10 \%$ of the total particulate organic carbon. If successfully validated, this method may improve our in situ estimates of primary productivity.

\section{Introduction}

The Earth's climate is profoundly influenced by the ocean biological pump, which absorbs $\mathrm{CO}_{2}$ from the atmosphere and transfers it to the deep ocean in particulate and dissolved form. Despite its importance, in situ information on this process is scarce and hard to obtain. Ocean particle dynamics can, however, be investigated by means of the inherent optical properties, which have strong potential to improve understanding of the biological pump.

The ocean carbon cycle is also dependent on the Earth's rotation. Indeed, the alternation between day and night

Published by Copernicus Publications on behalf of the European Geosciences Union. 
imposes a fundamental cycle on photosynthesis and the resulting conversion of atmospheric $\mathrm{CO}_{2}$ into particulate carbon. As a consequence, diel cycles of biogeochemical (Burney et al., 1982; Gasol et al., 1998) and optical (Siegel et al., 1989; Cullen et al., 1992; Marra, 1997) properties have been observed in the sunlit ocean.

The particulate beam-attenuation coefficient, $c_{\mathrm{p}}$, is an inherent optical property that exhibits diurnal variations (e.g., Siegel et al., 1989; Claustre et al., 1999). $c_{\mathrm{p}}$ depends, theoretically, on all the particles present in the water column (i.e., autotrophic and heterotrophic micro-organisms, as well as detritus and mineral particles). In practice however, $c_{\mathrm{p}}$ is mostly influenced by particles with equivalent spherical diameters (ESD) between 0.5 and $20 \mu \mathrm{m}$ (Pak et al., 1988). Within this size range, each particle pool is expected to contribute a variable fraction of $c_{\mathrm{p}}$, depending on its concentration, size, refractive index and shape (e.g., Stramski and Kiefer, 1991). In the open ocean, $c_{\mathrm{p}}$ is therefore well correlated with particulate organic carbon concentration (POC), but it has been difficult to ascribe variations of $c_{\mathrm{p}}$ to any specific particle pool, except when additional measurements are available.

Diel variations of particulate beam-attenuation coefficient are widespread in the surface ocean and have long been investigated as a non-invasive tool for deriving particle growth rates and productivity in situ (Siegel et al., 1989; Cullen et al., 1992; Stramska and Dickey, 1992; Walsh et al., 1995; DuRand and Olson, 1996; Claustre et al., 1999, 2008; Oubelkheir and Sciandra, 2008; Gernez et al., 2011). The diel cycle of $c_{\mathrm{p}}$ is generally characterized by an increase during daytime hours and a decrease at night suggesting that photosynthetic production of particles causes the observed $c_{\mathrm{p}}$ diel cycles (Siegel et al., 1989). These estimates are considered to be net values, because it is assumed that $c_{\mathrm{p}}$ tracks particle concentration, which, in turn, depends on both growth and losses (e.g. Siegel et al., 1989).

Laboratory investigations on phytoplankton cultures have provided significant insights on what controls diel cycles in $c_{\mathrm{p}}$. First, acclimated pico-phytoplankton $(<2 \mu \mathrm{m})$ populations are characterized by remarkably synchronized growth cycles, with division occurring mostly at night, despite the large genetic diversity of this group (Jacquet et al., 2001). Cell cycle synchronization to light availability has also been observed in larger phytoplankton, such as diatoms (Vaulot et al., 1986; Stramski and Reynolds, 1993), although these larger organisms are also known to be able to divide more than once per day (Chisholm and Costello, 1980). Second, diel variations in $c_{\mathrm{p}}$ are more correlated to changes in scattering cross-section $\left(\sigma_{b}\right.$, a measure of the light scattered by a single cell), than to changes in cell concentration (Stramski and Reynolds, 1993; Stramski et al., 1995; DuRand et al., 2002) and $\sigma_{b}$ appears to vary mostly with changes in cell size (DuRand et al. 2002; DuRand and Olson 1998, but see Stramski and Reynolds, 1993).
Flow cytometric analyses of in situ samples have confirmed and expanded laboratory results. Phytoplankton grow synchronously (i.e., grow during daylight and start dividing around dusk) in different ocean regions (DuRand, 1995; Vaulot and Marie, 1999; Jacquet et al., 2002; Binder and DuRand, 2002) and most of the diel variations in $c_{\mathrm{p}}$ can be ascribed to variations in the scattering properties of phytoplankton cells (DuRand, 1995; DuRand and Olson, 1996). Phytoplankton, however, seem to contribute only a fraction of the total $c_{\mathrm{p}}$ (DuRand and Olson, 1996; Claustre et al., 1999; Grob et al., 2007).

Most studies conducted on $c_{\mathrm{p}}$ diel cycles to date employed measurements at a single wavelength (typically $660 \mathrm{~nm}$ ). The particulate beam attenuation coefficient is, however, wavelength-dependent and its spectral shape can be approximated as a power law (e.g., Boss et al., 2001):

$c_{\mathrm{p}}(\lambda)=c_{\mathrm{p}}\left(\lambda_{0}\right)\left(\frac{\lambda}{\lambda_{0}}\right)^{-\xi}$,

where $c_{\mathrm{p}}\left(\lambda_{0}\right)$ is $c_{\mathrm{p}}$ at a reference wavelength $\lambda_{0}$ and $\xi$ is the spectral slope of $c_{\mathrm{p}}$.

Interestingly, a proxy for the "average particle size" can be derived from $\xi$. If the particle size distribution (PSD) can be represented by a power law (with slope $\eta$ ) that spans all possible sizes and particles are not absorbing, then the spectral slope of $c_{\mathrm{p}}$ and the slope of the PSD are approximately related according to $\xi \simeq \eta-3$ (Voltz, 1954 cited in van de Hulst, 1957; Morel, 1973; see also improved relationship presented by Boss et al., 2001). Nevertheless, the practical meaning of "average particle size" remains unclear. Similarly, it is uncertain how the spectral shape of $c_{\mathrm{p}}$ changes when deviations from the PSD power law model occur.

While diel cycles in $c_{\mathrm{p}}$ are well known, cycles in $\xi$ have only recently been reported in the open ocean. Two field studies showed that $\xi$ decreased during the day and increased at night suggesting that the relative size of the particles affecting $c_{\mathrm{p}}$ increased during the day and decreased at night (Oubelkheir and Sciandra, 2008; Slade et al., 2010). Laboratory studies have also shown diel variability in $\xi$ (Claustre et al., 2002; DuRand et al., 2002; Stramski and Reynolds, 1993; Stramski et al., 1995), but only DuRand et al. (2002) clearly reported that the spectral slope of the scattering coefficient decreased during the day and increased at night as recently observed in the field.

No attempt has so far been made to exploit the observed variations in $\xi$ to study diel cycles of phytoplankton. We reasoned that it should be possible to estimate gross growth rates by measuring diel changes in cell size, because the increase in cell volume during the day should be strictly a result of photosynthetic growth in synchronized cell populations (e.g., Sosik et al., 2003). The objective of the current study was thus to develop a methodology to quantitatively interpret the diel variations in spectral $c_{\mathrm{p}}$. Specifically, an existing mathematical model was adapted for simulating the diel variations 
in size and optical properties of a population of phytoplankton cells. This model was then fitted to in situ measurements of spectral $c_{\mathrm{p}}$ to infer physiological parameters of this population.

The population model and approach adopted here is similar to the one employed by Sosik et al. (2003) to infer eco-physiological parameters of a Synechococcus population from a time series of in situ flow cytometry measurements. The main difference is that $c_{\mathrm{p}}$ data are related to all particles present in the water column. Thus, the challenge here is to identify the most likely population that is responsible for the diel cycle in $c_{\mathrm{p}}$.

\section{Methods}

The data analyzed in this study were collected during the summer of 2008 in the framework of the "Biogeochemistry from the Oligotrophic to the Ultra-oligotrophic Mediterranean" (BOUM) cruise. Specifically, we report on measurements collected during a three-day intensive sampling station that took place in the center of a gyre located in the Algero-Provençal basin (approximately at $39^{\circ} \mathrm{N}$ and $7^{\circ} \mathrm{E}$; Moutin et al., 2011). Water samples were collected continuously from a custom-made clean underway system including a Teflon diaphragm pump to draw water from just under the ship's hull (about $9 \mathrm{~m}$ ). The average chlorophyll and POC concentrations during this long duration station were approximately $0.05 \mathrm{mg} \mathrm{m}^{-3}$ and $50 \mathrm{mg} \mathrm{m}^{-3}$, respectively (Pujo-Pay et al., 2011). Because of the large computational cost of the optimization procedure described below, the inversion scheme was tested on a single day of measurements during which cloud cover was almost absent, as verified by incident PAR measurements.

\subsection{In situ optical measurements}

Continuous $c_{\mathrm{p}}$ measurements were conducted with by a WetLabs ACs hyperspectral absorption and attenuation meter (400-750 nm, every $5 \mathrm{~nm}$ ) and two WetLabs C-star transmissometers (nominally centered at 532 and $660 \mathrm{~nm}$ ). Data were processed following protocols described elsewhere (Dall'Olmo et al., 2009; Slade et al., 2010). Briefly, the particulate optical signals were calculated by subtracting from the bulk raw measurements the optical signals generated by $0.2 \mu \mathrm{m}$-filtered seawater. Such signals were automatically recorded every hour for ten minutes (Dall'Olmo et al., 2009; Slade et al., 2010). All instruments had 25-cm pathlengths. The suitability of the pumping system for conducting these measurements was verified by comparing C-star based $c_{\mathrm{p}}(660)$ values measured on the flow-through system with surface (average between 5 and $15 \mathrm{~m}$ ) $c_{\mathrm{p}}$ values derived from another C-star transmissometer (nominally, $660 \mathrm{~nm}$, $25-\mathrm{cm}$ pathlength) that was mounted on the CTD. CTD values of $c_{\mathrm{p}}$ were derived by subtracting the minimum $c_{\mathrm{p}}$ value measured at each station from the upcast profiles. This comparison yielded a mean value for the ratio $c_{\mathrm{p}}^{\text {flow }}: c_{\mathrm{p}}^{\mathrm{CTD}}$ of 0.998 and a standard deviation of $0.071(N=42)$. Photosynthetically active radiation (PAR) was determined with a calibrated LI-COR Li-190 quantum sensor mounted on the front mast of the ship.

\subsection{Flow cytometric measurements}

$2 \mathrm{ml}$ samples were collected every hour in cryo-vials from the pump-system described above, fixed using 1\% (final) formaldehyde, flash frozen in liquid nitrogen and preserved at $-80^{\circ} \mathrm{C}$ (Troussellier et al., 1995). Samples were later thawed at room temperature and analyzed with a FACSCan flow Cytometer (BD-Biosciences), equipped with an air-cooled argon laser $(488 \mathrm{~nm}, 15 \mathrm{~mW})$. Phytoplanktonic cells were enumerated according to right-angle light scatter properties (SSC, roughly related to cell size), and the orange $(585 / 42 \mathrm{~nm})$ and red $(>650 \mathrm{~nm})$ fluorescence emissions from phycoerythrin and chlorophyll pigments, respectively. $1 \mu \mathrm{m}$ beads (Polysciences) were added to all samples as internal standard. Data were acquired through the CellQuest software (BD-Biosciences). Four cell types were determined: "Syn", for Synechococcus sp., "euk" for small eukaryotes, and two nanoplankton groups ("nano-1" and "nano-2") according to their increasing SSC and red fluorescence properties. Approximate size ranges for the eukaryotic groups are 1-3 $\mu \mathrm{m}$ for "euk", 3-5 $\mu \mathrm{m}$ for "nano-1" and 5-8 $\mu \mathrm{m}$ for "nano-2". Bacterial counts were obtained on the same sample, after SyBRGreen-I staining (Marie et al., 1997) allowing measurements of their side scattering and green fluorescence $(530 / 30 \mathrm{~nm})$.

\subsection{Dissolved organic carbon measurements}

Discrete samples were collected from the outlet of the flowthrough system approximately every three hours during the long duration station. The method, standards and accuracy assessment of the dissolved organic carbon (DOC) determination is described in detail in Pujo-Pay et al. (2011).

\subsection{Size-dependent model of cell growth}

A discrete time- and size-structured model of cell growth was adapted for the purpose of this study (Gage et al., 1984; Smith, 1996; Arino et al., 2002). The details of the model are reported in the given references, but we describe briefly its main characteristics and the modifications implemented.

The model simulates the biovolume dynamics of a population of phytoplankton cells that is subdivided into $n$ discrete classes each with a given average size. The cell classes are further divided into two sub-categories: "new born" and "mature". Both new born and mature cells can grow in size, provided light is available, but only mature cells can divide. When a mature cell divides, two new born cells are generated, each with volume equal to half the volume of the mature 
Table 1. Definitions and units of symbols (see also Table 2).

\begin{tabular}{|c|c|c|}
\hline Parameter & Definition & Units \\
\hline$c_{\mathrm{p}}$ & particulate beam-attenuation coefficient & $\mathrm{m}^{-1}$ \\
\hline$c_{\mathrm{p} 1, \mathrm{t}}$ & time-varying beam attenuation coefficient & $\mathrm{m}^{-1}$ \\
\hline$c_{\mathrm{p} 0}$ & background beam attenuation coefficient & $\mathrm{m}^{-1}$ \\
\hline$i^{\mathrm{P}}$ & index for all size classes & - \\
\hline$j$ & index for mature size classes & - \\
\hline$m$ & real part of relative refractive index & - \\
\hline$n$ & total number of size classes & - \\
\hline$n_{\mathrm{b}}$ & number of "new-born" size classes & - \\
\hline$n_{\mathrm{m}}$ & number of "mature" size classes & - \\
\hline$t$ & iteration number & iter \\
\hline$v_{t}$ & vector of cell biovolumes at iteration $t$ & $\mu \mathrm{m}^{3} \mathrm{~cm}^{-3}$ \\
\hline $\mathbf{A}_{\mathrm{t}}$ & projection matrix at iteration $t$ & - \\
\hline$D_{i}$ & mean cellular diameter for size class $i$ & $\mu \mathrm{m}$ \\
\hline$M$ & fractional volume increment from one size class to the following & - \\
\hline PAR & above-surface photosynthetically active radiation & $\mu$ moles $\mathrm{m}^{-2} \mathrm{~s}^{-1}$ \\
\hline$Q_{\mathrm{c}, \mathrm{i}, \mathrm{t}}(\lambda)$ & spectral efficiency factor for attenuation for class $i$ and iteration $t$ & - \\
\hline$Q_{\mathrm{c}, \mathrm{i}, \mathrm{t}}^{\mathrm{ACs}}(\lambda)$ & ACs spectral efficiency factor for attenuation for class $i$ and iteration $t$ & - \\
\hline$T$ & iteration period & days/iter \\
\hline$\tilde{\beta}_{i}$ & phase function for size class $i$ & $\mathrm{sr}^{-1}$ \\
\hline$\eta$ & PSD slope & - \\
\hline$\vartheta$ & scattering angle & degrees \\
\hline$\xi$ & spectral slope of $c_{\mathrm{p}}$ & - \\
\hline$\Lambda_{t}$ & division efficiency at iteration $t$ & - \\
\hline
\end{tabular}

mother cell (see Tables 1 and 2 for symbols definitions and units).

During the illuminated part of the 24 hours, all cells grow and mature cells can divide. At night cell growth is assumed to be negligible, but division can continue in mature cells. All cells are subject to a loss rate $\zeta$ that is assumed to be constant, but with different rates between day and night. The nighttime part of the $24 \mathrm{~h}$ was defined by the changes in trend of $c_{\mathrm{p}}(690)$ and, in practice, corresponded to the part of the 24-h period during which PAR was approximately smaller than $70 \mu$ moles $\mathrm{m}^{-2} \mathrm{~s}^{-1}$.

Since modeled cells grow exponentially in discrete time steps, the number of size classes is dependent on the cell growth rate and the length of the model iteration (Arino et al., 2002). Here, the iteration period was fixed to $30 \mathrm{~min}$, the maximum growth rate was set to 2 day $^{-1}$ and the resulting total number of classes was 12 . These classes were equally sub-divided between new born and mature cells (i.e., $n=n_{b}+n_{m}$, where $n_{b}$ and $n_{m}$ are the numbers of "new-born" and "mature" cells, respectively). Although the number of size classes is known, the average diameter of each size class is determined by the model parameters and cannot be specified a priori.
The model is formally expressed by the following system of difference equations:

$\boldsymbol{v}_{\mathrm{t}+1}=(1-\zeta) \mathbf{A}_{\mathrm{t}} \boldsymbol{v}_{\mathrm{t}}$,

where $\boldsymbol{v}_{\mathrm{t}}$ is the vector with the biovolume of each class at iteration $\mathrm{t}, \zeta$ is the loss rate and $\mathbf{A}_{\mathrm{t}}$ is the Leslie or projection matrix at iteration $t$ (Caswell, 2001). The expression for $\mathbf{A}_{t}$ is presented in Eq. (3) for a simplified case (i.e., $n_{\mathrm{b}}=n_{\mathrm{m}}=3$ ):

$\mathbf{A}_{\mathrm{t}}=$

$$
\left(\begin{array}{llllll}
1-\gamma_{\mathrm{t}} & 0 & 0 & M \gamma_{\mathrm{t}} \delta_{1, \mathrm{t}} & 0 & 0 \\
M \gamma_{\mathrm{t}} & 1-\gamma_{\mathrm{t}} & 0 & 0 & M \gamma_{\mathrm{t}} \delta_{2, \mathrm{t}} & 0 \\
0 & M \gamma_{\mathrm{t}} & 1-\gamma_{\mathrm{t}} & 0 & 0 & M \gamma_{\mathrm{t}} \delta_{3, \mathrm{t}} \\
0 & 0 & M \gamma_{\mathrm{t}} & 1-\gamma_{\mathrm{t}} & 0 & 0 \\
0 & 0 & 0 & M \gamma_{\mathrm{t}}\left(1-\delta_{1, \mathrm{t}}\right) & 1-\gamma_{\mathrm{t}} & 0 \\
0 & 0 & 0 & 0 & M \gamma_{\mathrm{t}}\left(1-\delta_{2, \mathrm{t}}\right) & 1-\gamma_{\mathrm{t}}
\end{array}\right)
$$

Here $\gamma_{\mathrm{t}}$ and $\delta_{j, \mathrm{t}}$ are the fractions of biomass in a given class that grow enough to pass to the next class and that divide in the $j$ mature class, respectively; and $M=2^{\frac{1}{n_{\mathrm{b}}}}$ is the fractional volume increment for a cell growing from one size class to the following (for more details see Arino et al., 2002).

The main diagonal of $\mathbf{A}_{\mathrm{t}}$ (red elements) specifies the fraction of biomass that remains in the same class. The lower diagonal (blues elements) of $\mathbf{A}_{t}$, instead, describes the growth from one class to the following. Finally, the upper diagonal 
Table 2. Definitions, ranges and units of optimized model parameters.

\begin{tabular}{|c|c|c|c|c|}
\hline \multirow[t]{2}{*}{ Parameter } & \multirow[t]{2}{*}{ Definition } & \multicolumn{2}{|c|}{ Range } & \multirow[t]{2}{*}{ Units } \\
\hline & & $\min$ & $\max$ & \\
\hline$\delta_{j}$ & $\begin{array}{l}\text { fraction of cells that divides in mature size class } \\
j \text { at each iteration }\end{array}$ & 0 & 1 & $1 /$ iter \\
\hline$\zeta_{\mathrm{d}}$ & $\begin{array}{l}\text { fraction of cells lost at each iteration during the } \\
\text { day }\end{array}$ & 0 & $4 / T$ & 1/iter \\
\hline$\zeta_{\mathrm{n}}$ & $\begin{array}{l}\text { fraction of cells lost at each iteration during the } \\
\text { night }\end{array}$ & 0 & $4 / T$ & $1 /$ iter \\
\hline$\mu_{\max }$ & volume-specific growth rate & 0 & 2 & 1/day \\
\hline$\xi_{0}$ & spectral slope of background $c_{\mathrm{p}}$ & -2 & 2 & - \\
\hline$c_{\mathrm{p} 0}(500)$ & background $c_{\mathrm{p}}$ at $500 \mathrm{~nm}$ & 0 & 0.09 & $m^{-1}$ \\
\hline$k_{\mathrm{PAR}}$ & half-saturation constant for growth & 0 & 2000 & $\mu$ moles $\mathrm{m}^{-2} \mathrm{~s}^{-1}$ \\
\hline$v_{\mathrm{nb} 0}$ & biovolume of class $n_{\mathrm{b}}$ at $t=t_{0}$ & 10 & $10^{5}$ & $\mu \mathrm{m}^{3} \mathrm{~cm}^{-3}$ \\
\hline$D_{\min }$ & minimum cellular diameter & 0.2 & 20 & $\mu \mathrm{m}$ \\
\hline
\end{tabular}

(black non-zero elements) of $\mathbf{A}_{\mathrm{t}}$ represents cell division or the transfer of biomass from mature to new-born cells.

Each row $i$ of the matrix $\mathbf{A}_{\mathrm{t}}$ describes the interactions of the cells in size class $i$ with the cells in the other size classes during a given model iteration. For example, the third row of $\mathbf{A}_{\mathrm{t}}$ informs us that the total biovolume of cells belonging to class 3 increases due to the growth of cells in class 2 (the $M \gamma_{\mathrm{t}}$ term in the second column, third row) and decreases because part of the biovolume of class 3 grows enough to pass to class 4 (the $1-\gamma_{t}$ term in the third column, third row). Similarly, the biovolume of class 4 in $\mathbf{A}_{t}$ decreases due to growth (the $1-\gamma_{\mathrm{t}}$ term in the fourth column, fourth row) and, as a consequence, the biovolumes of class 1 and 5 increase (the $M \gamma_{\mathrm{t}} \delta_{1, \mathrm{t}}$ and $M \gamma_{\mathrm{t}}\left(1-\delta_{1, \mathrm{t}}\right)$ terms in the fourth column, first and fifth rows, respectively).

$\gamma_{\mathrm{t}}$ was assumed to be constant for each size class (Sosik et al., 2003) and parametrized as a function of PAR:

$\gamma_{\mathrm{t}}=\left(\mu_{\mathrm{max}} \frac{\mathrm{PAR}_{\mathrm{t}}}{k_{\mathrm{PAR}}+\mathrm{PAR}_{\mathrm{t}}}\right) \frac{T}{M-1}$

where $\mu_{\mathrm{max}}$ and $k_{\mathrm{PAR}}$ are optimization parameters (see below) and the factor $T /(M-1)$ is used to convert the growth rate into the fraction of population that grows to the next class at each iteration (Arino et al., 2002). The subscript $t$ indicates quantities that are dependent on iteration number (i.e., time). Similarly, loss rates were independent of size class (Eq. 2).

$\delta_{\mathrm{j}, \mathrm{t}}$ was assumed to be a linear function of size class and its magnitude during the course of the day was modulated by an inverse function of light according to:

$\delta_{\mathrm{j}, \mathrm{t}}=\delta_{\max } \frac{j}{n_{\mathrm{m}}} \Lambda_{\mathrm{t}} ; \quad j=1, \ldots, n_{\mathrm{m}}$

where $\Lambda_{\mathrm{t}}=1-\mathrm{PAR}_{\mathrm{t}} / \max \left(\mathrm{PAR}_{\mathrm{t}}\right)$ and $\delta_{\max }$ is the value of $\delta$ in the last mature size class (index $n_{\mathrm{m}}$ ) when $\Lambda_{\mathrm{t}}=1$. Here, $\Lambda_{\mathrm{t}}$ imposes a linear decrease in division efficiency with increasing PAR, in accord with the hypothesis that natural populations minimize DNA damage by avoiding division when
UV radiation is high (Vaulot et al., 1995; Vaulot and Marie, 1999). $\Lambda_{t}$ forces division to zero when PAR reaches its maximum. This parametrization was selected because it allowed us to modulate division rates without introducing excessive complexity in the model.

The solution of Eq. (2) is the distribution of biovolumes in each size class as a function of time. This distribution is then converted into a number distribution (see below) and used to simulate the optical properties of the cell population.

\subsection{Simulation of optical properties}

The particulate beam-attenuation coefficient was assumed to be composed of two spectrally dependent parts: a background component, $c_{\mathrm{p} 0}(\lambda)$, that was constant throughout the simulation and a time-varying component, $c_{\mathrm{p} 1, \mathrm{t}}(\lambda)$, dependent on the dynamics of the cell population (this is similar to the assumption of Cullen and Lewis, 1995). The cell concentration of each class, $N_{i}$, was computed by dividing the biovolume in each class by its mean cellular volume $v_{i}=M^{i-1} v_{\min }$, where $v_{\min }=\pi / 6 D_{\min }^{3}$ (i.e., cells were assumed to be spherical; Arino et al., 2002). The refractive index of the cell population relative to that of seawater $(m)$ was assumed to be a real number (i.e., absorption was neglected) and constant (in practice the values 1.04, 1.06 and 1.08 were used, Aas 1996). The former assumption is supported by the negligible (i.e., $\leq 2.5 \%$ ) contribution of particulate absorption to $c_{\mathrm{p}}$ above $550 \mathrm{~nm}$ in our data set (data not shown). The latter is in agreement with laboratory results (DuRand et al., 2002; DuRand and Olson, 1998), although it may not apply in all cases (Stramski and Reynolds, 1993).

The spectral efficiency factors for attenuation for each class and iteration, $Q_{\mathrm{c}, \mathrm{i}, \mathrm{t}}^{\mathrm{ACs}}(\lambda)$, were computed using a standard Mie code (Bohren and Huffman, 1983), accounting for the acceptance angle of the ACs transmissometer (i.e., $\vartheta_{0}=0.93$ 
degrees; Boss et al. 2009):

$Q_{\mathrm{c}, i, t}^{\mathrm{ACs}}(\lambda)=2 \pi Q_{\mathrm{c}, i, t}(\lambda) \int_{\vartheta_{0}}^{\pi} \tilde{\beta}_{i, t}(\lambda) \sin \vartheta d \vartheta$

where $i$ is the size-class index, $Q_{\mathrm{c}, i, t}(\lambda)$ and $\tilde{\beta}_{i, t}(\lambda)$ are the efficiency factor for attenuation and the spectral phase function, respectively, for size class $i$ and $\vartheta$ is the scattering angle. In practice, a look-up table was employed to speed up computations.

The spectral beam-attenuation coefficient of the population of cells undergoing diel cycles and for the background were then computed as:

$c_{\mathrm{p} 1, \mathrm{t}}(\lambda)=\frac{\pi}{4} \sum_{i=1}^{r} N_{i, t} D_{i, t}^{2} Q_{\mathrm{c}, i, t}^{\mathrm{ACs}}(\lambda)$,

$c_{\mathrm{p} 0}(\lambda)=c_{\mathrm{p} 0}\left(\lambda_{0}\right)\left(\frac{\lambda}{\lambda_{0}}\right)^{-\xi_{0}}$

Both $c_{\mathrm{p} 0}\left(\lambda_{0}\right)$ and $\xi_{0}$ are optimization parameters (see below). In this study, $\lambda_{0}=500 \mathrm{~nm}$, but the results are not affected by this choice.

Finally, the simulated spectral particulate beamattenuation coefficient was computed as:

$c_{\mathrm{p}, \mathrm{t}}(\lambda)=c_{\mathrm{p} 0}(\lambda)+c_{\mathrm{p} 1, \mathrm{t}}(\lambda)$.

\subsection{Model inversion}

The solutions to Eqs. (2) and (9) were used to simulate a time series of $c_{\mathrm{p}}$ values that was compared to in situ observations. To obtain a model solution, first the system (Eq. 2) was brought to steady state (the system was solved for 100 iterations, i.e., about 3 months). The resulting biovolume distribution was normalized by the biovolume of size class $n_{\mathrm{b}}$ and multiplied by the parameter $v_{\mathrm{nb} 0}$ to obtain the initial conditions for the following simulation. The system was then solved at each iteration for the entire period and the timevarying spectral $c_{\mathrm{p}}$ was computed.

The model parameters were estimated by minimizing the following cost function:

$\chi^{2}=\sum_{\lambda} \sum_{t}\left[\frac{c_{\mathrm{p}, \mathrm{t}}^{\mathrm{mod}}(\lambda)-c_{\mathrm{p}, \mathrm{t}}^{\mathrm{obs}}(\lambda)}{\sigma_{c p}}\right]^{2}$,

where $\sigma_{c p}$ is the uncertainty in $c_{\mathrm{p}}$ which was conservatively estimated as $0.1 \times c_{\mathrm{p}, \mathrm{t}}^{\mathrm{obs}}(\lambda)$.

The global optimization algorithm Adaptive Simulated Annealing (http://www.ingber.com/ASA-README. html) was employed to derive robust estimates of the model parameters, which were constrained within realistic ranges (see Table 2). To better constrain the fit at the extremes of the simulation period, the data set used for the fit was composed of one day of data repeated twice and in succession. Thus, the data to be fitted consisted of two identical days of data. To improve the ability of the cost function to detect the global minimum, simulated $c_{\mathrm{p}}$ values were compared to data smoothed by a median filter (window size of $2 \mathrm{~h}$ ). As traditional simulated annealing, the ASA algorithm introduces random variations in the search for the global optimum and is rather insensitive to initial values of the parameters, given enough time for the optimization. Nevertheless, to test the robustness of our results, the initial values of the parameters were selected randomly from uniformly distributed ranges (Table 2). In addition, the optimization was repeated multiple times for different values of the initial parameters and random seeds. The optimal parameters and their confidence intervals were finally determined from the regions of the solution space where the cost function was minimal and where the inferred phytoplankton carbon (see below) was smaller than $70 \%$ of the measured POC.

\subsection{Carbon estimates}

The size distribution of phytoplankton cells retrieved by the inversion scheme affords us with the ability to estimate the carbon biomass, $\mathrm{C}_{\phi}$, of the population of cells that drives the diel $c_{\mathrm{p}}$ cycle. Two methods were adopted.

First, the biovolume distribution was converted into phytoplankton carbon by means of published relationships between biovolume and carbon (Montagnes et al., 1994; Menden-Deuer and Lessard, 2000). Of these two studies, the former is considered more relevant to the oligotrophic conditions sampled in the current study, because it was based on data from cells ranging in ESD down to about $2 \mu \mathrm{m}$. In contrast, the relationship presented by Menden-Deuer and Lessard (2000) focuses mostly on larger cells (minimum ESD about $7 \mu \mathrm{m}$ ) and thus its application here depends on the conserved nature of the carbon-density vs. biovolume relationship found for large cells.

The second method employed to compute $\mathrm{C}_{\phi}$ is based on the linear correlation between the real part of the relative refractive index, $m$, and the intracellular carbon concentration, $c_{i}$ (Stramski, 1999), which has been confirmed for a variety of species spanning from small cyanobacteria to larger eukaryotes (DuRand et al., 2002): $c_{i}=3946 m-3922$, where $c_{i}$ is expressed in $\mathrm{kg} \mathrm{m}^{-3}$. Phytoplankton carbon was computed as the product of the estimated biovolume distribution and $c_{i}$.

Flow cytometry data were used for preliminary validation of the inverted $\mathrm{C}_{\phi}$ estimates. Specifically, the carbon biomass of different populations was computed from published values of carbon densities, assumed ranges of cell diameters and measured cellular abundances. Different values

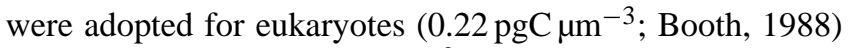

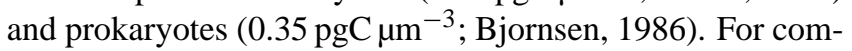
parison, the carbon biomass of heterotrophic bacteria was also estimated. 
Table 3. Median and central 68th percentile range of estimated model parameters for three different nominal values of $m$ (units as in Table 1 except for $\zeta_{\mathrm{d}}$ and $\zeta_{\mathrm{n}}$ that are reported in units of day ${ }^{-1}$ ).

\begin{tabular}{cccccccccc}
\hline$m$ & $\mu_{\max }$ & $\zeta_{\mathrm{d}}$ & $\zeta_{\mathrm{n}}$ & $D_{\min }$ & $v_{\mathrm{nb} 0}$ & $\delta_{1}$ & $c_{\mathrm{p} 0}(500)$ & $\xi_{0}$ & $k_{\mathrm{PAR}}$ \\
\hline 1.04 & $1.46(0.18)$ & $0.0001(0.0003)$ & $0.49(0.02)$ & $5.88(0.04)$ & $4958(384)$ & $0.57(0.06)$ & $0.062(0.001)$ & $0.54(0.02)$ & $1717(303)$ \\
1.06 & $1.40(0.21)$ & $0.0001(0.0003)$ & $0.48(0.02)$ & $4.03(0.02)$ & $3226(240)$ & $0.55(0.05)$ & $0.062(0.001)$ & $0.54(0.01)$ & $1658(401)$ \\
1.08 & $1.41(0.21)$ & $0.0001(0.0004)$ & $0.49(0.03)$ & $3.01(0.02)$ & $2328(214)$ & $0.55(0.07)$ & $0.062(0.001)$ & $0.54(0.02)$ & $1704(390)$ \\
\hline
\end{tabular}

\subsection{Growth rate estimates}

The average population volume at a given time, $\tau$, is:

$\bar{v}(\tau)=\frac{\sum v_{i}(\tau) N_{i}(\tau)}{\sum N_{i}(\tau)}$

where the sums are over all the size classes. The phytoplankton growth rate based on cellular volume, $\mu_{\mathrm{V}}$, was then computed between sunrise, $\tau_{1}$, and sunset, $\tau_{2}$, as:

$\mu_{\mathrm{V}}=\frac{1}{\tau_{2}-\tau_{1}} \log _{e}\left[\frac{\bar{v}\left(\tau_{2}\right)}{\bar{v}\left(\tau_{1}\right)}\right] f_{\mathrm{d}}$,

where $f_{\mathrm{d}}$ is the illuminated fraction of the day and $\tau$ is measured in days.

The important property of $\mu_{\mathrm{V}}$ is that it depends only on the relative distribution of biovolume across the different size classes (Eq. 11) and not on its absolute value. $\mu_{\mathrm{V}}$ (and $\gamma_{\mathrm{t}}$ ) can thus be determined independently of losses (i.e., $\zeta_{\mathrm{d}}$ ), since the model is able to estimate the relative size of the cells.

\section{Results}

The $c_{\mathrm{p}}$ time series displayed typical diel cycles that were spectrally dependent (Fig. 1a). As a consequence, distinct trends between day and night were observed in the spectral slope of $c_{\mathrm{p}}$, with increasingly flatter slopes during the day and a steepening in the spectra at night (Fig. 1b). Other quantitative spectral differences were also evident: the peakto-peak variations of $c_{\mathrm{p}}(550)$ were smaller than those of $c_{\mathrm{p}}(750)$ and the maximum value of $c_{\mathrm{p}}(550)$ was broader and lasted about three hours longer than that at $c_{\mathrm{p}}(750) . c_{\mathrm{p}}$ spectra were, in general, smooth decreasing functions of wavelengths, as previously observed (inset in Figure 1b; Boss et al., 2001).

Figure 2 presents the time series of flow cytometric abundances (left column) and relative side scattering (right column). To quantitatively identify significant periods in these time series, Lomb-Scargle normalised periodograms (Press et al., 1992) were computed (solid grey lines in Fig. 2). Results were different for the abundance and scatter data. The only cell population that showed a highly significant period of 1 day in abundance was "euk". "syn" was characterised by two periods ( 0.8 and 1.3 days) and all the other groups did not have significant periods near 1 day. On the other hand,
Table 4. Median and central 68th percentile range of cell population parameters estimated from model outputs for three different nominal values of $m$ (units as in Table 1). $\bar{D}_{\text {avg }}$ and $\bar{N}_{\text {tot }}$ are the 24-h averages of $D_{\text {avg }}$ and $N_{\text {tot }}$, respectively. $\mu_{\mathrm{V}}$ is the population biomass-specific growth rate defined in Eq. 12.

\begin{tabular}{cccc}
\hline$m$ & $\bar{D}_{\text {avg }}$ & $\bar{N}_{\text {tot }}$ & $\mu_{\mathrm{V}}$ \\
\hline 1.04 & $6.78(0.05)$ & $196(12)$ & $0.65(0.02)$ \\
1.06 & $4.66(0.03)$ & $393(25)$ & $0.65(0.02)$ \\
1.08 & $3.53(0.03)$ & $650(57)$ & $0.65(0.02)$ \\
\hline
\end{tabular}

the relative side scatter data from "syn", "euk" and "nano-1" all showed a highly significant period of 1 day. Thus, cycles with a period of 1 day (i.e., diel cycles) were more evident in side scatter measurements than in abundances. These diel patterns are typical in oceanic regions (e.g., Vaulot and Marie, 1999) and have been previously observed in the surface Mediterranean Sea (Jacquet et al., 2002; Oubelkheir and Sciandra, 2008).

Modeled $c_{\mathrm{p}}$ values were in agreement with measured $c_{\mathrm{p}}$ with relative residuals $\left(c_{\mathrm{p}}^{\mathrm{mod}} / c_{\mathrm{p}}^{\mathrm{obs}}-1\right)$ spanning $\pm 2 \%$ (Fig. 3). Estimates of model parameters for three different values of the refractive index are presented in Table 3. The relative uncertainties of the parameters were typically below $24 \%$. Most parameters were independent of the refractive index, which suggests that they can be estimated accurately, provided the model assumptions are correct. On the other hand, the estimates of $D_{\min }$ and $v_{\mathrm{nb} 0}$ depended on the value of $m$ selected for the optimization (Table 3), as did the population time- and size-average diameter and total number of cells (Table 4). These parameters therefore cannot be estimated independently of $m$ (see also Discussion section).

Cellular promotion rate $\left(\gamma_{\mathrm{t}}\right)$ did not reach full saturation and volume-average division rates peaked at the end of the afternoon (Fig. 4). As in Sosik et al. (2003), $\gamma_{t}$ is a two parameter function of light, but it displayed considerably lower values in our study. This could be due to the very different environments where the two studies have been conducted (i.e., productive coastal waters vs. oligotrophic open ocean) or to the different phytoplankton groups under analysis (Synechococcus vs. all phytoplankton and most likely nanoeukaryotes). Instantaneous division rates peaked at dusk (Fig. $4 \mathrm{~b}$ ) and were thus also qualitatively similar to the results 

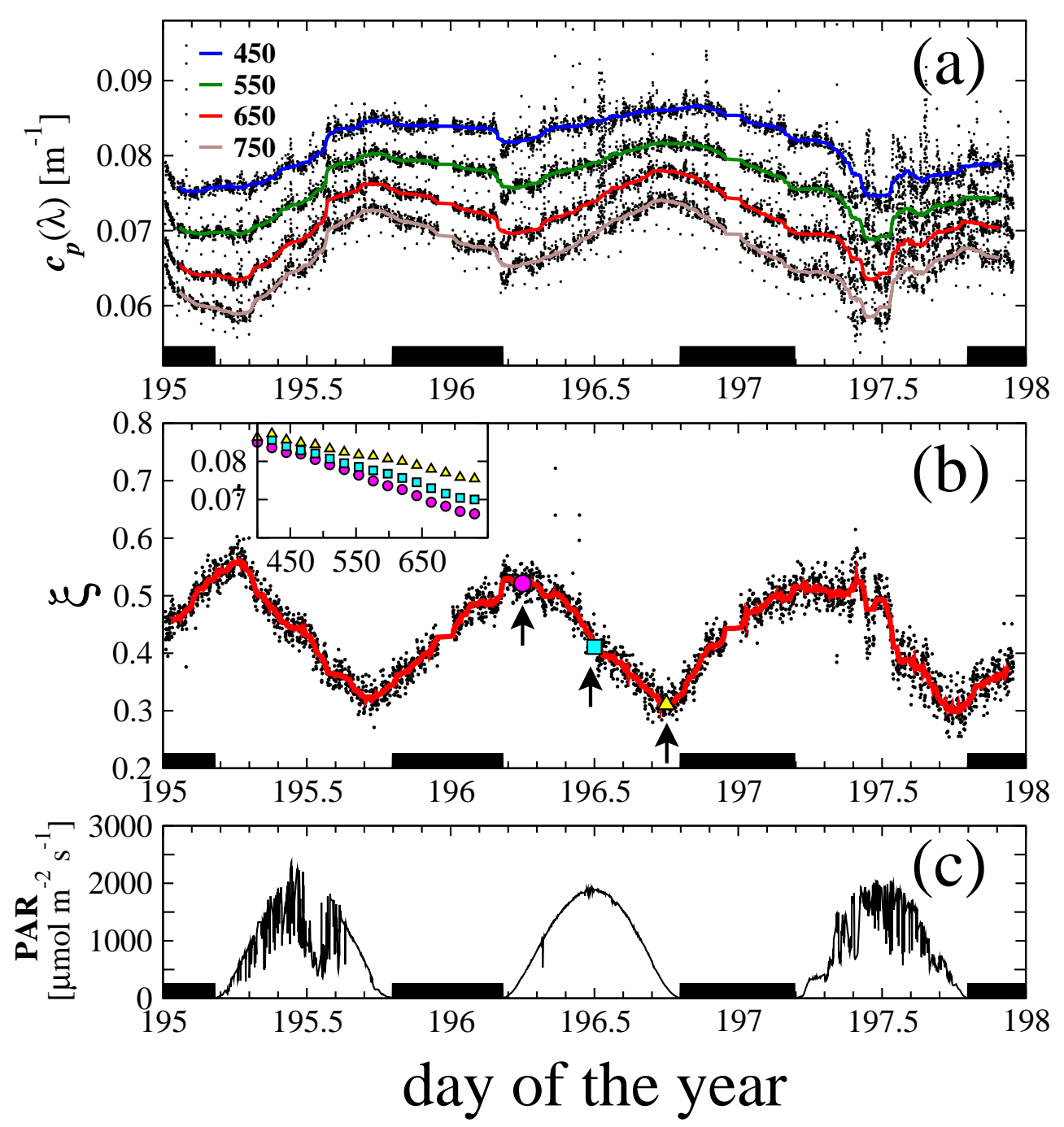

Fig. 1. Time series of data collected at the long duration station. (a) Particulate beam-attenuation coefficient at selected wavelengths. Black dots are the original data, solid lines are moving medians ( $2 \mathrm{~h}$ window). (b) Spectral slope of $c_{\mathrm{p}}$ computed between 550 and $750 \mathrm{~nm}$ (spectra become steeper as $\xi$ increases, see Eq. 1). The inset presents typical $c_{\mathrm{p}}$ spectra as a function of wavelength (nm) at selected times of the day (see arrows in the $\xi$ time series). (c) Photosynthetically available radiation.

Table 5. Phytoplankton and heterotrophic bacterial carbon $\left(\mathrm{mg} \mathrm{m}^{-3}\right)$ estimated from flow cytometric cell abundances, equivalent spherical diameters (ESD) and published carbon densities. $\mathrm{C}_{\phi}$ is the total phytoplankton carbon, $\mathrm{C}_{\mathrm{HB}}$ is the carbon of heterotrophic bacteria. Different

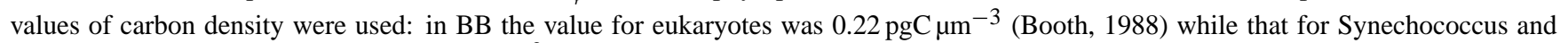

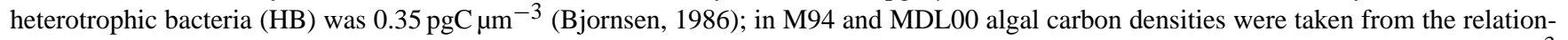
ships published by Montagnes et al. (1994) and Menden-Deuer and Lessard (2000), respectively. HB carbon density was 0.148 pgC $\mu m^{-3}$

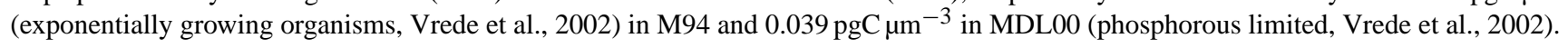

\begin{tabular}{cccccccc}
\hline & Nano2 & Nano1 & Euk & Syn & HB & $\mathrm{C}_{\phi}$ & $\mathrm{C}_{\phi}+\mathrm{C}_{\mathrm{HB}}$ \\
\hline ESD $(\mu \mathrm{m})$ & $5-8$ & $3-5$ & $1-3$ & $0.8-1.0$ & $0.4-0.8$ & & \\
cells ml $^{-1}$ & $291(43)$ & $359(50)$ & $205(32)$ & $6123(507)$ & $342907(41368)$ & & \\
\hline BB & $4.2-17.2$ & $1.1-5.2$ & $0.0-0.6$ & $0.6-1.1$ & $4.0-32.2$ & $5.9-24.1$ & $9.9-56.3$ \\
M94 & $2.0-8.1$ & $0.5-2.5$ & $0.0-0.3$ & $0.2-0.4$ & $1.7-13.6$ & $2.7-11.3$ & $6.9-39.0$ \\
MDL00 & $3.0-12.4$ & $0.9-4.1$ & $0.0-0.6$ & $0.4-0.7$ & $0.4-3.6$ & $4.3-17.7$ & $4.7-21.3$ \\
\hline
\end{tabular}




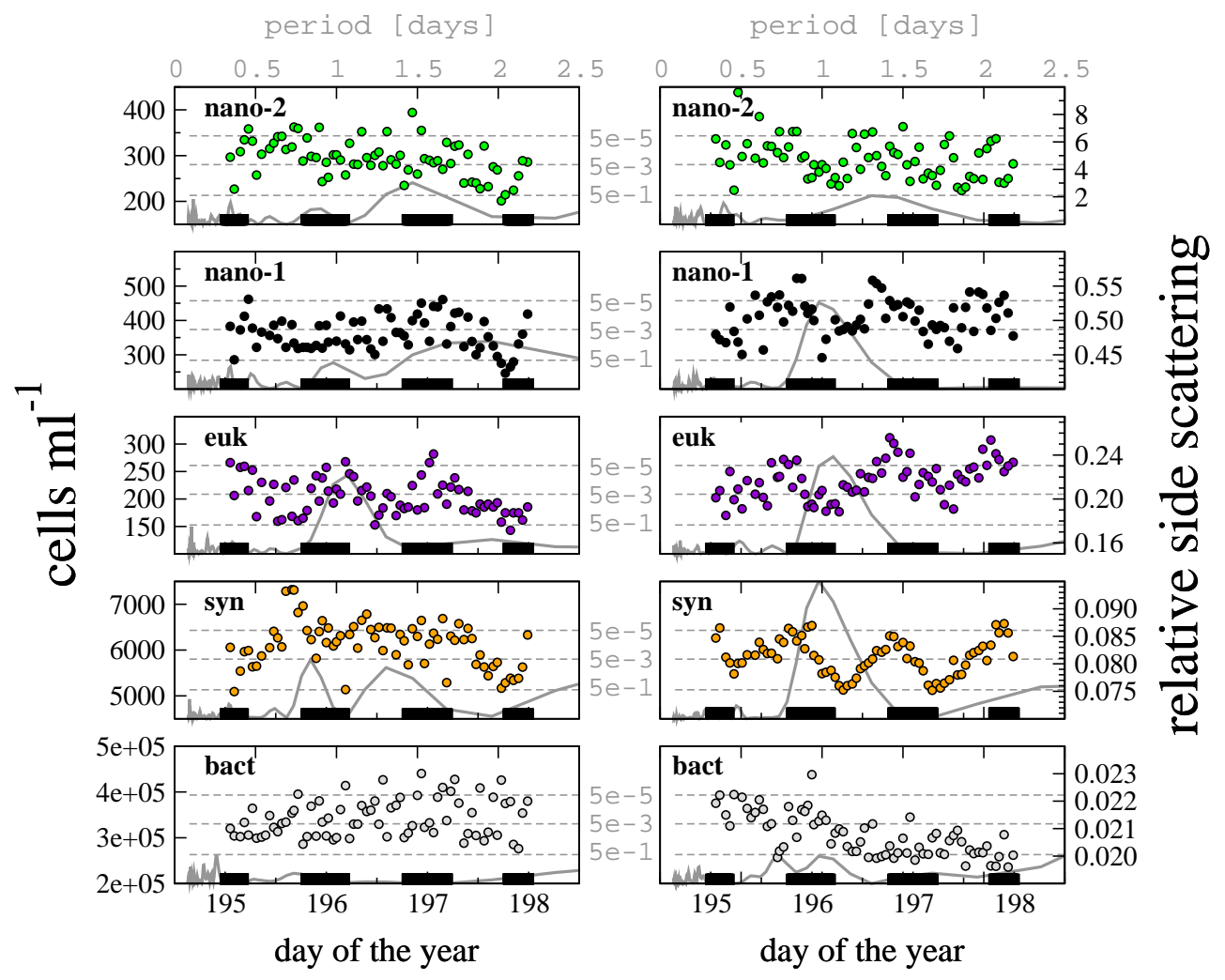

Fig. 2. Time series of flow cytometric estimates of cell abundance (left column) and side scattering relative to $1 \mu \mathrm{m}$ beads (right column). Black bars on the $\mathrm{x}$-axes indicate the night-time periods. Solid grey lines are Lomb-Scargle periodograms of each time series plotted as a function of period (upper x-axis). Horizontal dashed grey lines are three significance levels $(0.5,0.005,5 e-5)$ for the periodogram peaks. Prochlorococcus was not reliably detected by the instrument used for the analysis.

presented in Sosik et al. (2003) and other studies (e.g., Binder and DuRand, 2002).

Volume-based cellular growth rate $\left(\mu_{\mathrm{V}}\right)$ was relatively high, with a mean daily value of $0.65 \mathrm{day}^{-1}$ (Table 4). Cell losses were negligible during the day, but high at night and compensated daytime growth. These results are consistent with previous studies which indicated moderate to high growth rates in oligotrophic regions and near balance between day growth and night losses (Siegel et al., 1989; Lessard and Murrell, 1998; Claustre et al., 2008). The background value of $c_{\mathrm{p}}$ at $500 \mathrm{~nm}$ contributed about $75 \%$ of the measured $c_{\mathrm{p}}$, in agreement with the conclusions of other studies (e.g., DuRand and Olson, 1996; Claustre et al., 1999).

Figure 5 presents the size distribution of the cell population as a function of time for the median set of parameters and $m=1.06$. The cell population gradually increased in size during the illuminated part of the day as a consequence of photosynthetic growth. At dusk (20:24) the population was characterized by a relatively larger number of dividing cells (red empty circles in Fig. 5). As night started, cells divided, new born cells increased in number and the average size of the population decreased. These dynamics are further demonstrated in Fig. 6, where the total number of cells and their average scattering cross-section are plotted. From this figure it is evident that the model ascribes the observed increase in $c_{\mathrm{p}}$ during the illuminated part of the day to an increase in cellular scattering, rather than cell abundance (compare Fig. 6a and b), as suggested by previous studies (e.g., Stramski et al., 1995; DuRand et al., 2002). The $c_{\mathrm{p}}$ dynamics at night are instead related to both variations in cell abundance and scattering cross-section (Fig. 6).

In general, our results are in qualitative agreement with flow cytometry studies that show increases in cell size from dawn to dusk and opposite patterns at night, with negligible changes in cell abundances (Vaulot and Marie, 1999; Jacquet et al., 2002). The specific shape of the modeled size distribution, however, is slightly different from those of observed phytoplankton distributions which are typically log-normal (e.g., Fig. 2a in Stramski et al., 1995 or Fig. 4 in Sosik et al., 2003). This difference is likely caused by the simplified model formulation (e.g., it may require a more complex formulation for $\delta$ or implementation of asymmetric cell division). In addition, $\sigma_{b}$ decreases faster than flow-cytometric side scattering (compare right column of Figs. 2 and $6 \mathrm{~b}$ ), which is likely related to the assumed function describing the probability of division for each mature cell ( $\delta$, Eq. 5). Finally, 


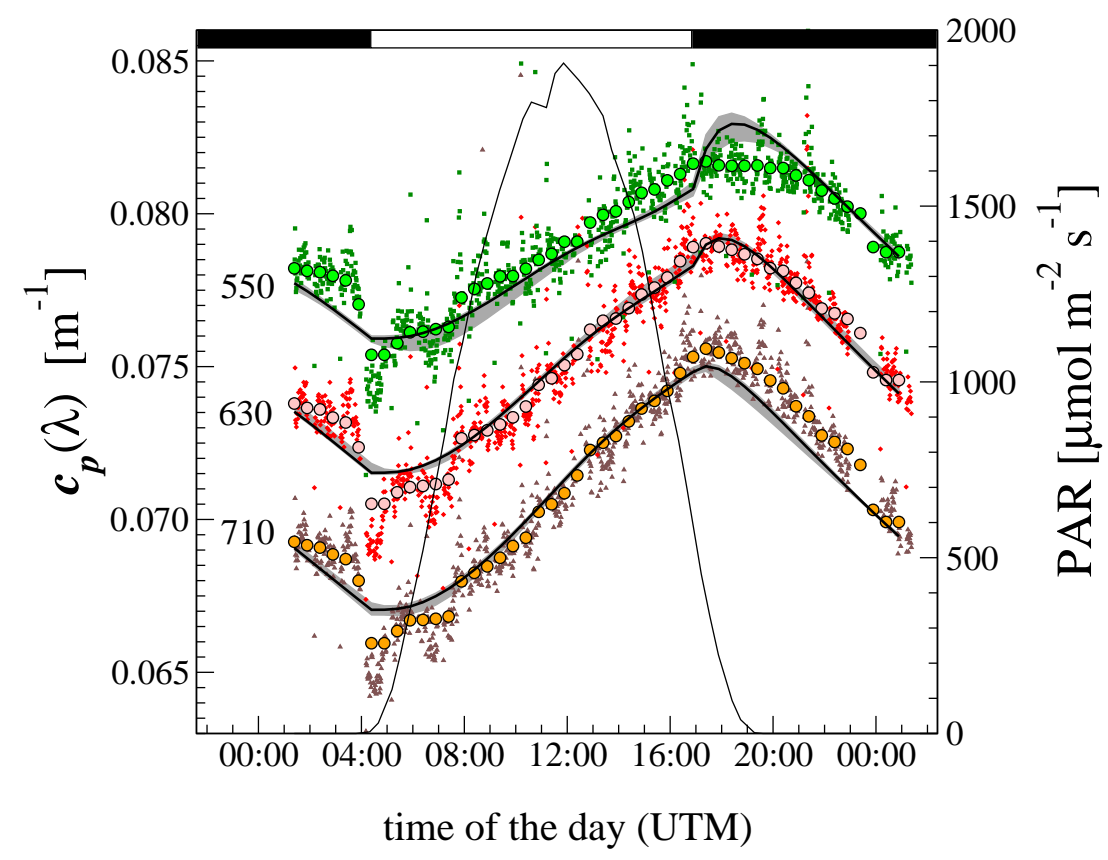

Fig. 3. Comparison between measured and modeled $c_{\mathrm{p}}$ for day of the year 196. $c_{\mathrm{p}}$ measured at different wavelengths (bold numbers) are presented as small colored dots together with their median filtered values used for the optimization (large circles). Gray shaded areas and thinner black lines are the $95 \%$ confidence intervals and median, respectively, of modeled $c_{\mathrm{p}}$ at the same wavelengths $(n=1.06)$. The photosynthetically available radiation (PAR) is plotted as the thin bell-shaped black line. Black and white bar at the top indicate the division-only and growth-and-division phases of the model, respectively.
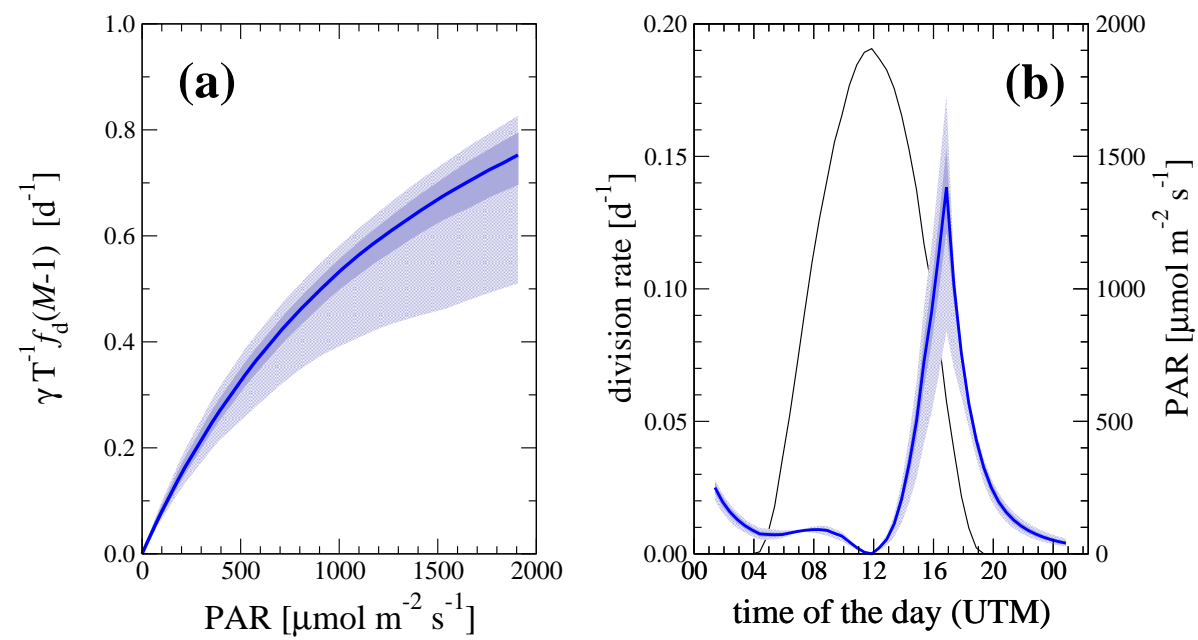

Fig. 4. Model parameters inferred for $n=1.06$. (a) Inferred promotion rate as a function of PAR and (b) volume-average division rates as a function of hour of the day; the black line is the PAR. Thick blue line: median value; dark blue shaded area: central 68th percentile range (approximately equal to the standard deviation for normal distributions); light blue shaded area: $95 \%$ confidence intervals.

it is worth mentioning that the total number of cells retrieved by the inversion scheme is in relatively good agreement with the the concentrations of eukaryotic cells determined by flow cytometry (compare Figs. 6a and 2).
Phytoplankton carbon estimates based on flow cytometric cell abundances were characterized by large uncertainties due to uncertainties in cell size and carbon densities (Table 5). Nonetheless, nano-eukaryotes ("nano-2" and "nano1") contributed the majority of the phytoplankton carbon, while pico-eukaryotes ("euk") and Synechococcus ("syn") 


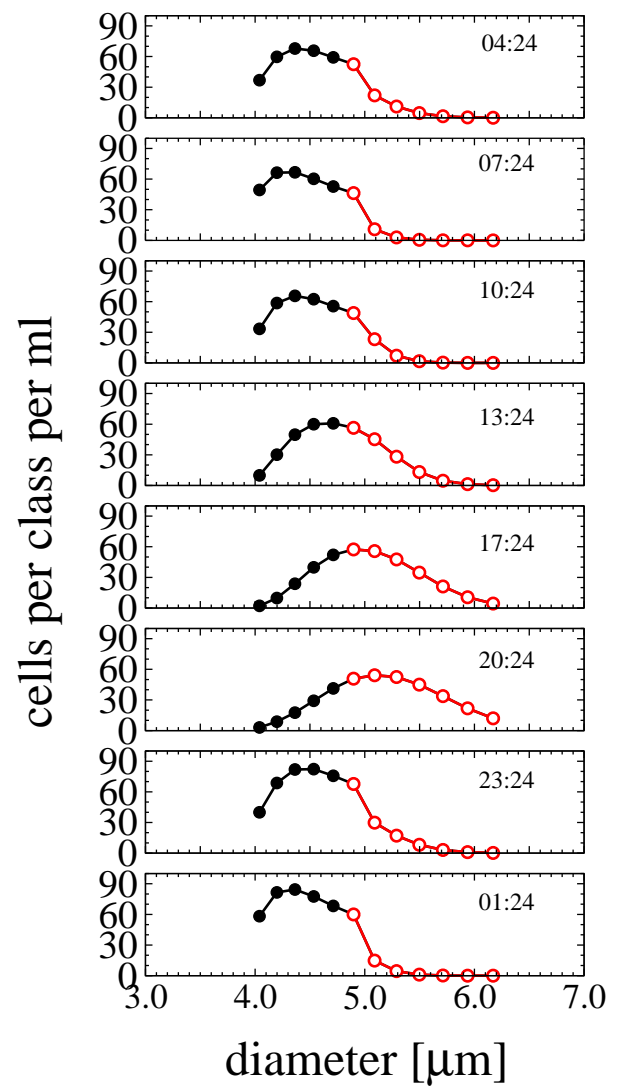

Fig. 5. Model output for cell concentrations for each class plotted from top to bottom every three hours for day of the year 196 (results obtained for the median of the optimal parameters and $n=1.06$ ). Black filled circles: newborn cells; red open circles: dividing cells. Numbers inside plots indicate the time of the day in UTM.

contributed a considerably smaller fraction of $\mathrm{C}_{\phi}$. Depending on the parametrization, $\mathrm{C}_{\phi}$ contributed from 5 to $48 \%$ of the measured POC (i.e., $50 \mathrm{mg} \mathrm{m}^{-3}$, Pujo-Pay et al., 2011).

The model inferred phytoplankton carbon biomass, $\mathrm{C}_{\phi}^{m}$, varied by about $15 \%$ when $m$ was employed in the calculation and accounted for about $10 \%$ of the observed POC (Table 6). Instead, variations of up to a factor 2 in the inferred $\mathrm{C}_{\phi}$ were observed when only the PSD and published carbon densities were employed in the calculation, due to the observed covariation between $m$ and $\bar{D}_{\text {avg }}$.

\section{Discussion}

Similarly to our study, other investigators have previously employed a size-structured population model to infer ecophysiological parameters of a Synechococcus population from continuous in situ flow-cytometry data (Sosik et al., 2003). The novelty of the present work is that the dynamics of both the magnitude and the spectral shape of $c_{\mathrm{p}}$ are exploited to characterize the phytoplankton population that
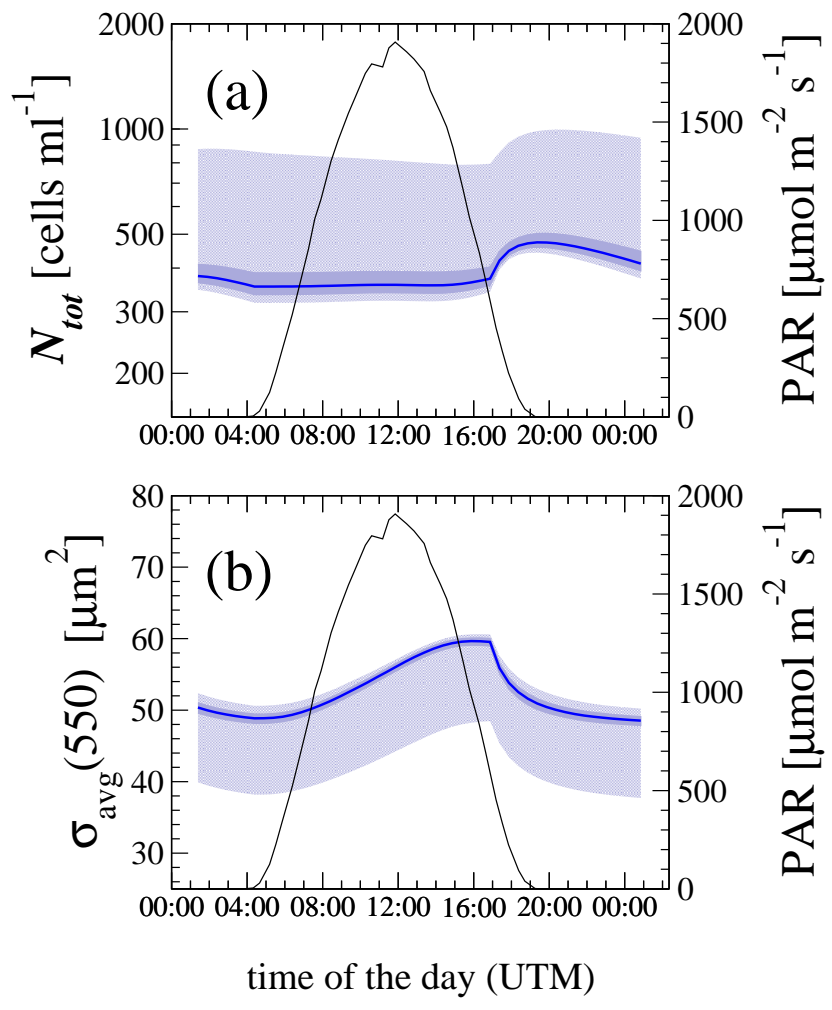

Fig. 6. Inferred total number of cells (a) and average population scattering cross-section at $550 \mathrm{~nm}$ (b) as a function of time $(n=1.06)$. Thick blue lines: median values; dark blue shaded areas: central 68th percentile range (approximately equal to the standard deviation for normal distributions); light blue shaded areas: $95 \%$ confidence intervals. The photosynthetically available radiation (PAR) is plotted as a thin black line.

Table 6. Phytoplankton carbon $\left(\mathrm{mg} \mathrm{m}^{-3}\right)$ inferred from model outputs by means of the biovolume- $m$ relationship, $\mathrm{C}_{\phi}^{m}$ and from the model biovolume and the carbon-biovolume relationships by Montagnes et al. (1994), $\mathrm{C}_{\phi}^{\mathrm{M} 94}$, and Menden-Deuer and Lessard (2000), $\mathrm{C}_{\phi}^{\mathrm{MLO0}}$.

\begin{tabular}{lccc}
\hline & 1.04 & 1.06 & 1.08 \\
\hline $\mathrm{C}_{\phi}^{m}$ & $6.0(0.4)$ & $5.6(0.4)$ & $5.2(0.4)$ \\
$\mathrm{C}_{\phi}^{\mathrm{M} 94}$ & $3.3(0.2)$ & $2.2(0.1)$ & $1.6(0.1)$ \\
$\mathrm{C}_{\phi}^{\mathrm{ML00}}$ & $4.3(0.3)$ & $2.8(0.2)$ & $2.1(0.2)$ \\
\hline
\end{tabular}

most likely is responsible for the diel variations in $c_{\mathrm{p}}$. In addition, for the first time to our knowledge, our model exploits empirical relationships on optical parameters (i.e., refractive index and size distribution) to infer phytoplankton carbon from in situ diel cycles of spectral $c_{\mathrm{p}}$. 


\subsection{Partitioning $c_{\mathrm{p}}$}

It has long been recognized that the background component of $c_{\mathrm{p}}$ can cause significant underestimation of growth rates calculated from diel cycles of $c_{\mathrm{p}}$ (e.g., Siegel et al., 1989; Cullen et al., 1992). Here, a simple model was employed to partition the measured $c_{\mathrm{p}}$ into background and time-varying components. In doing so, the model infers the size distribution of the cell population that is responsible for the diel variations in $c_{\mathrm{p}}$, as well as other eco-physiological parameters. This is important because the estimated physiological rates are no longer dependent on the background $c_{\mathrm{p}}$ value and the population of particles that most likely affects $c_{\mathrm{p} 1}$ can now be (partially) characterized.

Some of the model parameters $\left(D_{\min }\right.$ and $\left.v_{\mathrm{nb} 0}\right)$, however, were found to be correlated with the refractive index, suggesting that their estimates are unreliable. The correlation between $m$ and $D_{\min }$ (or, in general, $D$ ) is expected, because these variables appear as a product in the expression for the phase shift parameter, $\rho=2 \pi D \lambda^{-1}(m-1)$, that approximately controls $Q_{\mathrm{c}}$ (van de Hulst, 1957). Thus, $(m-1) D$ is a first independent model parameter. On the other hand, $D_{\min }$ and $v_{\text {nb0 }}$ (and similarly $\bar{D}_{\text {avg }}$ and $\bar{N}_{\text {tot }}$ ) are inversely related because $c_{\mathrm{p} 1}$ can be safely approximated as $c_{\mathrm{p} 1} \approx \bar{N}_{\text {tot }} \bar{G} \bar{Q}_{\mathrm{c}} \propto$ $\left(\bar{N}_{\text {tot }} \bar{D}^{2}\right) \bar{Q}_{\mathrm{c}}$, since the size distribution of the population that generates the diel component of $c_{\mathrm{p}}$ is rather narrow (van de Hulst, 1957). $\bar{N}_{\text {tot }} \bar{D}^{2}$, is thus a second parameter that partially overlaps with $(m-1) D$.

\subsection{Growth and loss rate estimates}

The biomass-specific growth rate estimates presented in Table 4 and based on Eq. (12) implicitly incorporate losses due to phytoplankton respiration and, therefore, are not gross growth rates sensu strictu. Nevertheless, these estimates are growth rates independent of losses such as grazing and sinking. The ability of the model to decompose the spectral optical measurements and simultaneously follow biovolume and cell size is the reason why growth and losses can be independently differentiated. Indeed, while biovolume depends both on growth and losses, the average population cell size (Eq. 12) should be independent of losses, if these are not size specific.

For comparison, the "diurnal rate of variations" (Eq. (6) in Gernez et al., 2011), scaled by $f_{\mathrm{d}}$ and computed from $c_{\mathrm{p}}$ at 450 and $730 \mathrm{~nm}$ were 0.07 and $0.14 \mathrm{~d}^{-1}$, respectively, and significantly lower than the values $\left(0.65 \mathrm{~d}^{-1}\right)$ presented in Table 4. Hence, estimates of growth rate based on singlewavelength $c_{\mathrm{p}}$ measurements, beside being significantly underestimated due to the background $c_{\mathrm{p} 0}$, appear to be wavelength dependent and should be used with caution.

Reliable loss estimates during the day and night are fundamental for deriving dependable eco-physiological parameters (Cullen and Lewis, 1995). Flow cytometry data did not show large decreases in cell abundances during the day (with the exception of "euk") and thus is, in general, consistent with negligible losses during the day. In addition, the maximum side scattering values achieved at the end of the daylight period (Figure 2) are consistent with cells dividing at the beginning of the night (e.g., Vaulot and Marie, 1999; Binder and DuRand, 2002) and should correspond to an increase in cell numbers. Such increase is not observed (Fig. 2), however, indicating that cell losses at night are approximately balancing cell division.

Micro-zooplankton (i.e., $<200 \mu \mathrm{m}$ ) are the main predators of phytoplankton in oligotrophic regions (Calbet, 2008, and references therein). Although data are still scarce, some evidence suggests that even these smaller organisms display diel vertical migrations (Denis et al., 2000; Perez et al., 2000) and cycles in grazing activity (Tsuda et al., 1989), possibly as a consequence of the light cycle (Economou et al., 2008). Interestingly, diel cycles in grazing activity cannot be resolved by the dilution technique (one of the main experimental tools for determining microzooplankton grazing rates), because samples are incubated for $24 \mathrm{~h}$ (Landry and Hassett, 1982), as verified for open-ocean tropical/subtropical waters (representative of oligotrophic conditions) in the references cited by Calbet and Landry (2004). In addition, if vertical migrations of micro-zooplankton, as observed in the cited studies for the North-western Mediterranean Sea, are widespread in the open ocean, then bottle incubation may introduce further biases in the estimation of grazing rates as they would effectively prevent any migrating organism to enter (or leave) the incubated water sample.

An alternative or complementary hypothesis could be that the large loss rates inferred by our model at night are caused by large, vertically migrating, filter feeders (e.g., tunicates). These organisms can be centimeters in size, but appear to be able to filter sub-micron particles by means of their fine mucous mesh (Sutherland et al., 2010) and could thus be responsible for the significant night time losses inferred by our model. The available Acoustic Doppler Current Profiler (ADCP) measurements partially support this hypothesis by showing the presence near the surface of relatively large organisms $(\sim 2 \mathrm{~cm})$ at night and their absence during the day (Fig. 7). Future investigations should nevertheless focus on validating the current inversion scheme by collecting, among others, in situ measurements of loss rates as well as groupspecific growth rates.

\subsection{Phytoplankton carbon estimates}

A novel output of our inversion scheme is the estimated carbon biomass of the phytoplankton population that most likely causes the measured diel cycle in $c_{\mathrm{p}}$. Estimates based on the conversion of biovolume into carbon biomass were associated with large uncertainties due to the discussed covariation between refractive index and diameter. On the other hand, phytoplankton carbon estimates based on biovolume and the carbon density derived from $m$ (i.e., $\mathrm{C}_{\phi}^{m}$ ) 


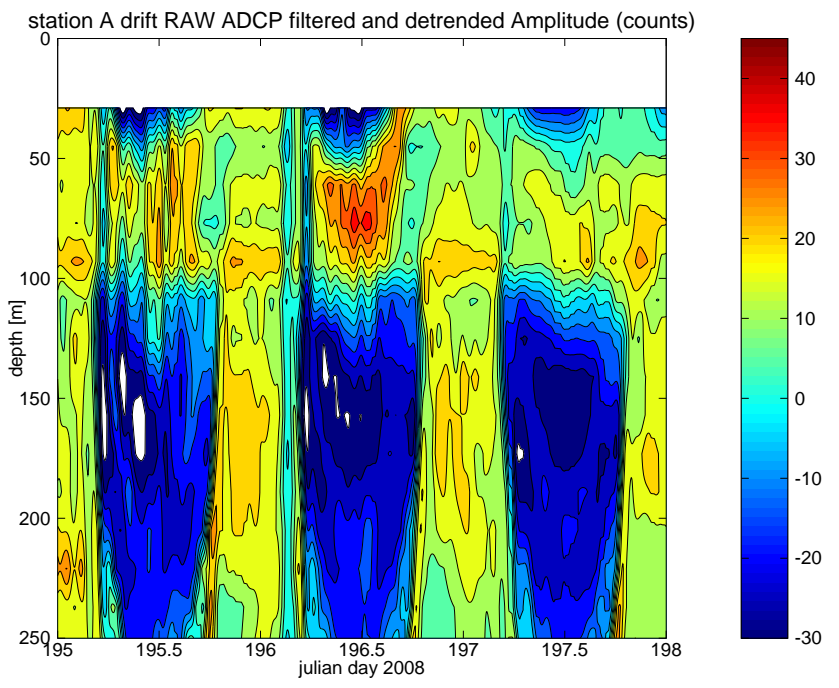

Fig. 7. Time series of vertical profiles of ADCP (78 khz) estimates of raw acoustic backscattering signal filtered (30 min window) and detrended to remove water absorption. The minimum bin depth was about $29 \mathrm{~m}$.

were more self-consistent and varied approximately between 5.2-6.0 $\mathrm{mgC} \mathrm{m}^{-3}$ for the different values of $m$ used. These estimates can be used to compute time- and size-averages of $c_{\mathrm{p} 1}^{*}=c_{\mathrm{p} 1}: \mathrm{C}_{\phi}^{m}$. At $670 \mathrm{~nm}$, the mean (st. dev.) $c_{\mathrm{p} 1}^{*}$ was equal to $3.4(0.1), 3.7(0.1)$ and $4.0(0.1) \mathrm{m}^{2} \mathrm{gC}^{-1}$ for $m=1.04,1.06$ and 1.08 respectively, in agreement with laboratory-based estimates measured on cells spanning diameters between 2 and $5 \mu \mathrm{m}$ (DuRand et al., 2002).

The inversion scheme, however, retrieves $\mathrm{C}_{\phi}^{m}$ of a phytoplankton population distributed over a limited range of diameters (about a factor of 1.5 between minimum and maximum values, Fig. 5) and likely underestimates the total $\mathrm{C}_{\phi}$. Thus, the inferred relative contribution of $\mathrm{C}_{\phi}^{m}$ to POC $(\sim 10 \%)$ is not inconsistent with previous estimates indicating that the $\mathrm{C}_{\phi}$ :POC ratio is typically around $20-40 \%$ in the upper oligotrophic ocean (e.g. DuRand et al., 2001).

\subsection{Productivity estimates}

Net primary productivity (NPP) was computed from the model output and compared to single-band $c_{\mathrm{p}}$ estimates. The difference in phytoplankton carbon biomass between dusk and dawn yielded a mean (st. dev.) NPP value of 2.5(0.2) $\mathrm{mgC} \mathrm{m}^{-3} \mathrm{~d}^{-1}$ for $m$ varying from 1.04 to 1.08 . On the other hand, the rate of POC increase between dusk and dawn was calculated from measurements of $c_{\mathrm{p}}(670)$ and yielded 3.4 and $4.7 \mathrm{mgC} \mathrm{m}^{-3} \mathrm{~d}^{-1}$, using a conversion factor between POC and $c_{\mathrm{p}}(670)$ of $2.47 \mathrm{~m}^{2} \mathrm{gC}^{-1}$ (Loisel et al., 2011) and $1.78 \mathrm{~m}^{2} \mathrm{gC}^{-1}$ (Oubelkheir and Sciandra, 2008), respectively.

The $c_{\mathrm{p}}^{*}$ values typically adopted to compute productivity from $c_{\mathrm{p}}$ cycles are derived empirically using bulk $c_{\mathrm{p}}$ and POC measurements. These $c_{p}^{*}$ are therefore dependent on the background components of both POC and $c_{\mathrm{p}}$ and assume that the same carbon-to-attenuation ratios exist for background and time-varying components of the particle pool. The differences found between $c_{\mathrm{p}}^{*}$ values taken from the literature and $c_{\mathrm{p} 1}^{*}$ derived from our model suggest that the conversion factors for $c_{\mathrm{p} 1}$ and $c_{\mathrm{p} 0}$ might have been significantly different in the current study. These differences can also explain the discrepancies in productivity highlighted above.

Particulate primary production based on ${ }^{14} \mathrm{C}$ additions was approximately $2.5 \mathrm{mgC} \mathrm{m}^{-3} \mathrm{~d}^{-1}$ at a depth of about $12 \mathrm{~m}$ (López-Sandoval et al., 2011) and thus in agreement with the estimate based on diurnal $\mathrm{C}_{\phi}^{m}$ variations, but lower (44\% and $88 \%$, respectively) than those estimated using POC variations. However, the $\mathrm{C}_{\phi}^{m}$-based NPP estimate is assigned by the model to a single population of cells, while NPP based on ${ }^{14} \mathrm{C}$ refers to the entire phytoplankton community. Thus, our model may force the dynamic population to be responsible for the entire NPP, because of the assumption that a single cell population drives the diel cycle of $c_{\mathrm{p}}$. Alternatively, the ${ }^{14} \mathrm{C}$ determinations could be underestimating the real NPP, for example because of artifacts due to bottle incubations (Claustre et al., 2008; Quay et al., 2010).

An independent, but nevertheless ${ }^{14} \mathrm{C}$-based, measurement of size-fractionated NPP at $12 \mathrm{~m}$ yielded a total value of about $3.1 \mathrm{mgC} \mathrm{m}^{-3} \mathrm{~d}^{-1}$, half of which (47\%) was due to cells smaller than $2 \mu \mathrm{m}$ (Lagaria, unpublished data). Assuming that this relative contribution of NPP is less affected by the above bottle artifacts than its absolute value, $c_{\mathrm{p}}$-based estimates of primary production could be missing a significant part of the total particulate production, because they appear to be most sensitive to cells larger than $2 \mu \mathrm{m}$. This conclusion is also supported by theoretical calculations that demonstrate that volume-normalized $c_{\mathrm{p}}$ of phytoplankton-like particles (i.e. $m=1.05$ ) is approximately a bell-shaped function with a maximum around $5 \mu \mathrm{m}$ (Fig. 6 in Boss et al., 2001). In other words, $c_{\mathrm{p}}$ is more sensitive to the biomass of phytoplankton with sizes around $5 \mu \mathrm{m}$ than to smaller or larger cells.

Finally, diurnal variations of DOC were also evident and of larger magnitude than the $c_{\mathrm{p}}$-inferred variations of POC (Figure 8). If the observed increase in DOC during the day was due to passive or active exudation of organic carbon from phytoplankton, then primary production estimates based on particle dynamics may be further underestimated.

\subsection{Limitations}

An important limitation of the current implementation of the technique is its large computational cost, which depends mostly on the need to repeat the optimization many times to ensure the resulting optimal parameters are robust. Despite each set of global optimizations being distributed to several parallel processors, relatively long running times (about $12 \mathrm{~h}$ with over $40 \mathrm{CPUs}$ ) were required to identify the global optima for each $m$. Nevertheless, we 


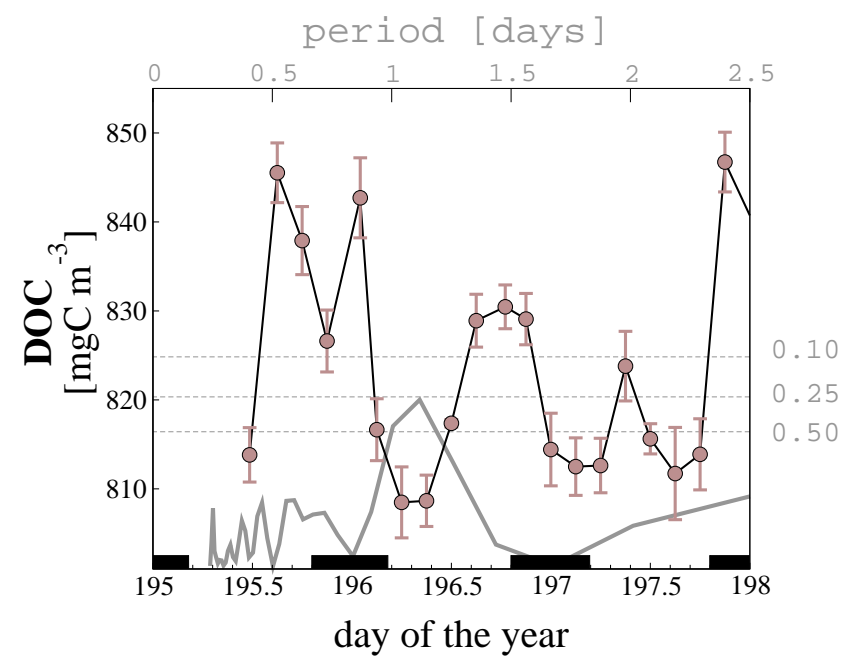

Fig. 8. Time series of dissolved organic carbon concentrations (error bars are standard deviations of duplicates). The solid grey line is the corresponding Lomb-Scargle normalized periodogram plotted as a function of period (upper axis). Horizontal dashed grey lines are three significance levels $(0.5,0.25,0.1)$ for the periodogram peaks.

expect that improved hardware and smarter algorithms will become available, making the current technique (or adaptation thereof) more affordable.

Limitations from the eco-physiological and optical point of view are stated in the model assumptions. Important issues include the assumption that only one population of cells is responsible for the observed cycle in $c_{\mathrm{p}}$ and the assumptions of constant loss rates and refractive index during the two simulated phases of the cell cycle. Other complexities of microbial food webs, such as mixotrophy (Talarmin et al., 2011), may further invalidate our hypothesis of absence of growth during the night.

Modeled and observed $c_{\mathrm{p}}$ values are in agreement, however, it is clear that the fit is not perfect and the largest deviations occur at the transition between day and night (i.e., Fig. 3). Different species are known to start dividing at different times (Vaulot and Marie, 1999; Binder and DuRand, 2002) and assuming a single species is responsible for all of the diel variations in $c_{\mathrm{p}}$ is likely the cause of the mismatch between model and observations. The time-discrete model potentially introduces additional discrepancies, especially at the transition between day an night when the model allows the loss rate to change. Furthermore, we assumed (as in Sosik et al. 2003) a growth rate that only depends on the intensity of light, which may also be questionable as it has been shown that synchronized cells may alter their growth rates depending on the stage of the cell cycle (Harding et al., 1981; Bruyant et al., 2005). It is, however, worth noticing that this assumption does not imply that nutrient limitation is a priori negligible, but that it has a constant intensity during the diel cycle. Further, it is possible that the time-varying population generates a time-varying detrital component that is ignored by our model, potentially skewing the interpretation of the inferred eco-physiological and morphological parameters. Finally, our analysis is based on the assumption that diurnal variations in vertical mixing do not influence the diel cycles in spectral $c_{\mathrm{p}}$, because these spectral measurements were only available from the flow-through system.

Nevertheless, these approximations represent a trade off between model complexity and information content of the data. It is unlikely that more parameters could be estimated from the available $c_{\mathrm{p}}$ data, but inclusion of additional independent pieces of information (e.g., angularly resolved scattering data) may permit greater complexity to be resolved and may yield more robust results. Future work, however, should first implement and validate the method under different environments, for example by exploiting carefully calibrated flow cytometry data (e.g., Green et al., 2003).

\section{Conclusions}

A model was employed to invert measurements of spectral particulate beam attenuation collected over a diel cycle. The model partitions $c_{\mathrm{p}}$ into constant and time-varying components and outputs novel, independent estimates of growth and loss rates, as well as the carbon biomass of the population of cells responsible for the measured variability in $c_{\mathrm{p}}$.

This technique is considerably different from previous work based on measurements at a single wavelength. Specifically, no assumptions are made regarding the background component of $c_{\mathrm{p}}$ and the carbon-to- $c_{\mathrm{p}}$ conversion factor. The derived growth and net diurnal productivity rates can be, as a consequence, significantly different from those estimated from single-band $c_{\mathrm{p}}$ cycles.

The method presented retains the appeal of previous work on $c_{\mathrm{p}}$ diel cycles as it only requires measurements of particulate beam-attenuation at multiple wavelengths. If successfully validated, it could provide a powerful tool to interpret diel cycles of $c_{\mathrm{p}}$ and assess the eco-physiological status of phytoplankton populations from in situ measurements, thus enhancing our understanding of the ocean carbon cycle.

Acknowledgements. The authors would like to thank the captain, chief engineer, electricians and crew of the N/O L'Atalante for their support during the cruise. S. Sakatahe is thanked for making available the "asamin" interface (http://faculty.arts.ubc.ca/ssakata/public_html/software/) which was employed to run the ASA algorithm within GNU Octave. $\mathrm{S}$. Bonnet is thanked for providing the Teflon pump used for the pumping system. M. Grant at PML is acknowledged for his help with distributed computing. S. Ciavatta is thanked for helpful discussions during model development and inversion. An anonymous reviewer is acknowledged for providing constructive criticisms. A thorough review by J. Cullen significantly improved an initial draft of this paper. G. D. O. and E. B. were supported 
through NASA grant NNX09AK30G and the UK National Centre for Earth Observation.

Edited by: C. Jeanthon

\section{References}

Aas, E.: Refractive index of phytoplankton derived from its metabolite composition, J. Plankt. Res., 18, 2223-2249, 1996.

Arino, J., Gouze, J. L., and Sciandra, A.: A discrete, size-structured model of phytoplankton growth in the chemostat - Introduction of inhomogeneous cell division size, J. Math. Biol., 45, 313-336, doi:10.1007/s002850200160, 2002.

Binder, B. J. and DuRand, M. D.: Diel cycles in surface waters of the equatorial Pacific, Deep-Sea Res. Part II - Topical Stud. Oceanogr., 49, 2601-2617, 2002.

Bjornsen, P. K.: Automatic-determination of bacterioplankton biomass by image-analysis, Appl. Environ. Microbiol., 51, 1199-1204, 1986.

Bohren, C. F. and Huffman, D. R.: Absorption and scattering of light by small particles, Wiley, New York, USA, 530 pp., 1983.

Booth, B. C.: Size classes and major taxonomic groups of phytoplankton at 2 locations in the subarctic Pacific-ocean in May and August, 1984, Marine Biol., 97, 275-286, 1988.

Boss, E., Twardowski, M. S., and Herring, S.: Shape of the particulate beam attenuation spectrum and its inversion to obtain the shape of the particulate size distribution, Appl. Opt., 40, 48854893, 2001.

Boss, E., Slade, W. H., Behrenfeld, M., and Dall'Olmo, G.: Acceptance angle effects on the beam attenuation in the ocean, Optics Expr., 17, 1535-1550, 2009.

Bruyant, F., Babin, M., Genty, B., Prasil, O., Behrenfeld, M. J., Claustre, H., Bricaud, A., Garczarek, L., Holtzendorff, J., Koblizek, M., Dousova, H., and Partensky, F.: Diel variations in the photosynthetic parameters of Prochlorococcus strain PCC 9511: Combined effects of light and cell cycle, Limnol. Oceanogr., 50, 850-863, 2005.

Burney, C. M., Davis, P. G., Johnson, K. M., and Sieburth, J. M.: Diel relationships of microbial trophic groups and in situ dissolved carbohydrate dynamics in the Caribbean sea, Marine Biol., 67, 311-322, 1982.

Calbet, A. and Landry, M. R.: Phytoplankton growth, microzooplankton grazing, and carbon cycling in marine systems, Limnol. Oceanogr., 49, 51-57, 2004.

Calbet, A.: The trophic roles of microzooplankton in marine systems, ICES J. Marine Sci., 65, 325-331, doi:10.1093/icesjms/fsn013, 2008.

Caswell, H.: Matrix population models, Sinauer, second edition edn., 2001.

Chisholm, S. W. and Costello, J. C.: Influence of environmentalfactors and population composition on the timing of cell-division in Thalassiosira-fluviatilis (bacillariophyceae) grown on light, J. Phycol., 16, 375-383, 1980.

Claustre, H., Morel, A., Babin, M., Cailliau, C., Marie, D., Marty, J. C., Tailliez, D., and Vaulot, D.: Variability in particle attenuation and chlorophyll fluorescence in the tropical Pacific: Scales, patterns, and biogeochemical implications, J. Geophys. Res.-Ocean., 104, 3401-3422, 1999.
Claustre, H., Bricaud, A., Babin, M., Bruyant, F., Guillou, L., Le Gall, F., Marie, D., and Partensky, F.: Diel variations in Prochlorococcus optical properties, Limnol. Oceanogr., 47, 1637-1647, 2002.

Claustre, H., Huot, Y., Obernosterer, I., Gentili, B., Tailliez, D., and Lewis, M.: Gross community production and metabolic balance in the South Pacific Gyre, using a non intrusive biooptical method, Biogeosciences, 5, 463-474, doi:10.5194/bg-5463-2008, 2008.

Cullen, J. J. and Lewis, M. R.: Biological processes and optical measurements near the sea surface: some issues relevant to remote sensing, J. Geophys. Res.-Ocean., 100, 13255-13266, 1995.

Cullen, J. J., Lewis, M. R., Davis, C. O., and Barber, R. T.: Photosynthetic characteristics and estimated growth-rates indicate grazing is the proximate control of primary production in the equatorial pacific, J. Geophys. Res.-Ocean., 97, 639-654, 1992.

Dall'Olmo, G., Westberry, T. K., Behrenfeld, M. J., Boss, E., and Slade, W. H.: Significant contribution of large particles to optical backscattering in the open ocean, Biogeosciences, 6, 947-967, doi:10.5194/bg-6-947-2009, 2009.

Denis, M., Martin, V., and Andersen, V.: Short-term variations of the vertical distribution of cyanobacteria in the open Mediterranean Sea, Sci. Mar., 64, 157-163, 2000.

DuRand, M. D.: Phytoplankton growth and diel variations in beam attenuation through individual cell analysis, Ph.D. thesis, MIT, WHOI, 1995.

DuRand, M. D. and Olson, R. J.: Contributions of phytoplankton light scattering and cell concentration changes to diel variations in beam attenuation in the equatorial Pacific from flow cytometric measurements of pico-, ultra- and nanoplankton, Deep-Sea Res. II-Topic. Stud. Oceanogr., 43, 891-906, 1996.

DuRand, M. D. and Olson, R. J.: Diel patterns in optical properties of the chlorophyte Nannochloris sp.: Relating individual-cell to bulk measurements, Limnol. Oceanogr., 43, 1107-1118, 1998.

DuRand, M. D., Olson, R. J., and Chisholm, S. W.: Phytoplankton population dynamics at the Bermuda Atlantic Time-series station in the Sargasso Sea, eep-Sea Res. II-Topic. Stud. Oceanogr., 48, 1983-2003, 2001.

DuRand, M. D., Green, R. E., Sosik, H. M., and Olson, R. J.: Diel variations in optical properties of Micromonas pusilla (Prasinophyceae), J. Phycol., 38, 1132-1142, 2002.

Economou, G., Christou, E. D., Giannakourou, A., Gerasopoulos, E., Georgopoulos, D., Kotoulas, V., Lyra, D., Tsakalis, N., Tzortziou, M., Vahamidis, P., Papathanassiou, E., and Karamanos, A.: Eclipse effects on field crops and marine zooplankton: the 29 March 2006 total solar eclipse, Atmos. Chem. Phys., 8, 4665-4676, doi:10.5194/acp-8-4665-2008, 2008.

Gage, T. B., Williams, F. M., and Horton, J. B.: Division synchrony and the dynamics of microbial-populations - A sizespecific model, Theor. Pop. Biol., 26, 296-314, 1984.

Gasol, J. M., Doval, M. D., Pinhassi, J., Calderon-Paz, J. I., GuixaBoixareu, N., Vaque, D., and Pedros-Alio, C.: Diel variations in bacterial heterotrophic activity and growth in the northwestern Mediterranean Sea, Marine Ecol.-Progr. Ser., 164, 107-124, 1998.

Gernez, P., Antoine, D., and Huot, Y.: Diel cycles of the particulate beam attenuation coefficient under varying trophic conditions in the northwestern Mediterranean Sea: Observations and model- 
ing, Limnol. Oceanogr., 56, 17-36, 2011.

Green, R. E., Sosik, H. M., Olson, R. J., and DuRand, M. D.: Flow cytometric determination of size and complex refractive index for marine particles: comparison with independent and bulk estimates, Appl. Opt., 42, 526-541, 2003.

Grob, C., Ulloa, O., Claustre, H., Huot, Y., Alarcon, G., and Marie, D.: Contribution of picoplankton to the total particulate organic carbon concentration in the eastern South Pacific, Biogeosciences, 4, 836-852, doi:10.5194/bg-4-836-2007, 2007.

Harding, L. W., Prezelin, B. B., Sweeney, B. M., and Cox, J. L.: Diel oscillations in the photosynthesis-irradiance relationship of a planktonic marine diatom, J. Phycol., 17, 389-394, 1981.

Jacquet, S., Partensky, F., Lennon, J. F., and Vaulot, D.: Diel patterns of growth and division in marine picoplankton in culture, J. Phycol., 37, 357-369, 2001.

Jacquet, S., Prieur, L., Avois-Jacquet, C., Lennon, J. F., and Vaulot, D.: Short-timescale variability of picophytoplankton abundance and cellular parameters in surface waters of the Alboran Sea (western Mediterranean), J. Plankt. Res., 24, 635-651, 2002.

Landry, M. R. And Hassett, R. P.: Estimating the grazing impact of marine micro-zooplankton, Marine Biol., 67, 283-288, 1982.

Lessard, E. J. and Murrell, M. C.: Microzooplankton herbivory and phytoplankton growth in the northwestern Sargasso Sea, Aqua. Microb. Ecol., 16, 173-188, 1998.

Loisel, H., Vantrepotte, V., Norkvist, K., Mériaux, X., Kheireddine, M., Ras, J., Pujo-Pay, M., Combet, Y., Leblanc, K., Dall'Olmo, G., Mauriac, R., Dessailly, D., and Moutin, T.: Characterization of the bio-optical anomaly and diurnal variability of particulate matter, as seen from scattering and backscattering coefficients, in ultra-oligotrophic eddies of the Mediterranean Sea, Biogeosciences, 8, 3295-3317, doi:10.5194/bg-8-3295-2011, 2011.

López-Sandoval, D. C., Fernández, A., and Marañón, E.: Dissolved and particulate primary production along a longitudinal gradient in the Mediterranean Sea, Biogeosciences, 8, 815-825, doi:10.5194/bg-8-815-2011, 2011.

Marie, D., Partensky, F., Jacquet, S., and Vaulot, D.: Enumeration and cell cycle analysis of natural populations of marine picoplankton by flow cytometry using the nucleic acid stain SYBR Green I, Appl. Environ. Microbiol., 63, 186-193, 1997.

Marra, J.: Analysis of diel variability in chlorophyll fluorescence, J. Marine Res., 55, 767-784, 1997.

Menden-Deuer, S. and Lessard, E. J.: Carbon to volume relationships for dinoflagellates, diatoms, and other protist plankton, Limnol. Oceanogr., 45, 569-579, 2000.

Montagnes, D. J. S., Berges, J. A., Harrison, P. J., and Taylor, F. J. R.: Estimating carbon, nitrogen, protein, and chlorophyll-a from volume in marine-phytoplankton, Limnol. Oceanogr., 39, 1044-1060, 1994.

Morel, A.: Advisory Group for Aerospace Research and Development, chap. Diffusion de la lumiere par les eaux de mer. Resultat experimentaux et approach theorique, NATO, 3.1.1-76, 1973.

Moutin, T., Van Wambeke, F., and Prieur, L.: The Biogeochemistry from the Oligotrophic to the Ultraoligotrophic Mediterranean (BOUM) experiment, Biogeosciences Discuss., 8, 8091-8160, doi:10.5194/bgd-8-8091-2011, 2011.

Oubelkheir, K. and Sciandra, A.: Diel variations in particle stocks in the oligotrophic waters of the Ionian Sea (Mediterranean), J. Marine Syst., 74, 364-371, 2008.

Pak, H., Kiefer, D. A., and Kitchen, J. C.: Meridional variations in the concentration of chlorophyll and microparticles in the North Pacific Ocean, Deep Sea Res., 35, 1151-1171, 1988.

Perez, M. T., Dolan, J. R., Vidussi, F., and Fukai, E.: Diel vertical distribution of planktonic ciliates within the surface layer of the NW Mediterranean (May 1995), Deep-Sea Res., 47, 479-503, 2000.

Press, W. H., Teukolsky, S. A., Vetterling, W. T., and Flannery, B. P.: Numerical recipes in C (2nd ed.): the art of scientific computing, Cambridge University Press, 1992.

Pujo-Pay, M., Conan, P., Oriol, L., Cornet-Barthaux, V., Falco, C., Ghiglione, J.-F., Goyet, C., Moutin, T., and Prieur, L.: Integrated survey of elemental stoichiometry $(\mathrm{C}, \mathrm{N}, \mathrm{P})$ from the western to eastern Mediterranean Sea, Biogeosciences, 8, 883899, doi:10.5194/bg-8-883-2011, 2011.

Quay, P. D., Peacock, C., Bjorkman, K., and Karl, D. M.: Measuring primary production rates in the ocean: Enigmatic results between incubation and non-incubation methods at Station ALOHA, Global Biogeochemical Cycles, 24, GB3014, doi:10.1029/2009GB003665, doi:10.1029/2009GB003665, 2010.

Siegel, D., Dickey, T., Washburn, L., Hamilton, M., and Mitchell, B.: Optical determination of particulate abundance and production variations in the oligotrophic ocean, Deep-Sea Res., 36, 211-222, 1989.

Slade, W. H., Boss, E., Dall'Olmo, G., Langner, M. R., Loftin, J., Behrenfeld, M. J., Roesler, C., and Westberry, T. K.: Underway and moored methods for improving accuracy in measurement of spectral particulate absorption and attenuation., J. Atmos. Ocean. Technol., 27, 1733-1746, 2010.

Smith, H. L.: A discrete, size-structured model of microbial growth and competition in the chemostat, J. Math. Biol., 34, 734-754, 1996.

Sosik, H. M., Olson, R. J., Neubert, M. G., Shalapyonok, A., and Solow, A. R.: Growth rates of coastal phytoplankton from timeseries measurements with a submersible flow cytometer, Limnol. Oceanogr., 48, 1756-1765, 2003.

Stramska, M. and Dickey, T. D.: Variability of biooptical properties of the upper ocean associated with diel cycles in phytoplankton population, J. Geophys. Res.-Ocean., 97, 17873-17887, 1992.

Stramski, D.: Refractive index of planktonic cells as a measure of cellular carbon and chlorophyll a content, Deep-Sea Res., 46, 335-351, 1999.

Stramski, D. and Kiefer, D.: Light scattering by microorganisms in the open ocean, Prog. Oceanogr., 28, 343-383, 1991.

Stramski, D. and Reynolds, R. A.: Diel variations in the opticalproperties of a marine diatom, Limnol. Oceanogr., 38, 13471364, 1993.

Stramski, D., Shalapyonok, A., and Reynolds, R. A.: Optical characterization of the oceanic unicellular cyanobacterium Synechococcus grown under a day-night cycle in natural irradiance, $\mathrm{J}$. Geophys. Res.-Ocean., 100, 13295-13307, 1995.

Sutherland, K. R., Madin, L. P., and Stocker, R.: Filtration of submicrometer particles by pelagic tunicates, Proc. Natl. Acad. Sci., 107, 15129-15134, doi:10.1073/pnas.1003599107, 2010.

Talarmin, A., Van Wambeke, F., Catala, P., Courties, C., and Lebaron, P.: Flow cytometric assessment of specific leucine incorporation in the open Mediterranean, Biogeosciences, 8, 253265, doi:10.5194/bg-8-253-2011, 2011.

Troussellier, M., Courties, C., and Zettelmaier, S.: Flow cytomet- 
ric analysis of coastal lagoon bacterioplankton and picophytoplankton - Fixation and storage effects, Est. Coast. Shelf Sci., 40, 621-633, 1995.

Tsuda, A., Furuya, K., and Nemoto, T.: Feeding of microzooplankton and macrozooplankton at the subsurface chlorophyll maximum in the sub-tropical north Pacific, Journal of Experimental Marine Biol. and Ecology, 132, 41-52, 1989.

van de Hulst, H. C.: Light scattering by small particles, Wiley, New York, USA, 470 pp., 1957.

Vaulot, D. and Marie, D.: Diel variability of photosynthetic picoplankton in the equatorial Pacific, J. Geophys. Res.-Ocean., 104, 3297-3310, 1999.

Vaulot, D., Olson, R. J., and Chisholm, S. W.: Light and dark control of the cell cycle in two marine phytoplankton species, Exp. Cell Res., 167, 38-52, 1986.
Vaulot, D., Marie, D., Olson, R. J., and Chisholm, S. W.: Growth of Prochlorococcus, a photosynthetic prokaryote, in the equatorial Pacific-ocean, Science, 268, 1480-1482, 1995.

Vrede, K., Heldal, M., Norland, S., and Bratbak, G.: Elemental composition $(\mathrm{C}, \mathrm{N}, \mathrm{P})$ and cell volume of exponentially growing and nutrient-limited bacterioplankton, Appl. Environ. Microbiol., 68, 2965-2971, doi:10.1128/AEM.68.6.2965-2971.2002, 2002.

Walsh, I. D., Chung, S. P., Richardson, M. J., and Gardner, W. D.: The diel cycle in the integrated particle load in the Equatorial Pacific - A comparison with primary production, Deep-Sea Res., 42, 465-477, 1995. 